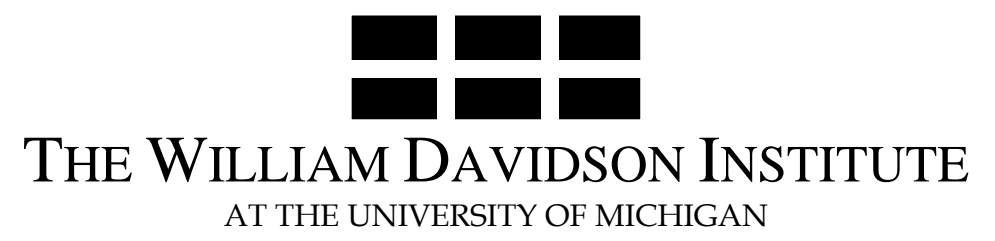

AT THE UNIVERSITY OF MICHIGAN

\title{
Financial Efficiency and the Ownership of Czech Firms
}

By: Evzen Kocenda, Jan Hanousek \& Michal Masika

William Davidson Institute Working Paper Number 1016

May 2011 


\title{
Financial Efficiency and the Ownership of Czech Firms
}

\author{
Jan Hanousek ${ }^{*}$, EvženKočenda ${ }^{* *}$, and Michal Mašika ${ }^{* * *}$
}

\begin{abstract}
In this paper we analyze the evolution of firm financial efficiency in the Czech Republic. Using a large panel of more than 400,000 Czech firm/years we study whether firms fully utilize their resources, how firm financial efficiency evolves over time, and how firm financial efficiency is determined by ownership structure. We employ a panel version of a stochastic production frontier model for the period 1996-2007 with time-invariant efficiency. We differentiate among various degrees of ownership concentration and their domestic or foreign origin. In a two-stage set-up we estimate the degree of firm inefficiency and then we estimate the effect of ownership structure on the distance from the efficiency frontier. Our results support the hypothesis that concentration and foreign ownership are positively related to financial efficiency.
\end{abstract}

Keywords: financial efficiency; ownership structure; firms; panel data; stochastic frontier JEL Classification: C33; D24; G32; L60; L80; M21

* CERGE-EI, Charles University and the Academy of Sciences, Prague; Anglo-American University, Prague; The William Davidson Institute, Michigan; and CEPR, London.

** CERGE-EI, Charles University and the Academy of Sciences, Prague; Anglo-American University, Prague; CESifo, Munich; OEI, Regensburg; The William Davidson Institute, Michigan; CEPR, London; and the Euro Area Business Cycle Network.

*** Ludwig-Maximilians-Universität München.

Part of this paper was written while Evžen Kočenda was a Visiting Fellow at the OsteuropaInstitut (OEI), Regensburg, whose hospitality is greatly appreciated. We are thankful for valuable comments from Richard Frensch, Stephan Huber, and Dieter Sadowski. We also benefited from presentations at OEI (Regensburg, 2011), Mendel University (Brno, 2011) and IAAEG (Trier, 2011). Support from GAČR grant No. 402/09/1595 is gratefully acknowledged. The usual disclaimer applies. 


\section{Introduction}

The economic reforms of the 1990s in Central and Eastern Europe (CEE) were aimed at creating competitive market economies and more efficient enterprises by firm restructuring, privatization, and supporting institutional reforms (Estrin et al., 2009). Still, there is a lack of reliable empirical evidence on medium- and long-term firm efficiency and the determinants of efficiency in post-transition economies in the CEE region (Estrin et al., 2009; Hanousek et al., 2007a). We fill this gap in the literature by analyzing the financial efficiency of Czech firms and how this efficiency is determined by ownership structures. We employ a stochastic production frontier model and use unique firm-level panel data of more than 400,000 firm/year observations for the period 1996-2007. Our results are in line with the theoretical predictions that concentration and foreign ownership are positively related to financial efficiency (Hill and Snell, 1989; Blomström et al., 2001) and shed light on many other subtleties of how ownership affects firm efficiency.

In our research we analyze two kinds of firms: privatized formerly state-owned enterprises (SOEs) and newly established firms. The privatization of the SOEs in the former command economies in Central and Eastern Europe has been at the center of a debate among economists and policy makers since the late 1980s. The SOEs were originally established to ensure a better provision of public goods as well as political control of production in centrally planned economies. However, they turned out not to be able to keep up with technical and innovative progress. For this reason both economists and policy makers expected SOEs' efficiency to increase after privatization under new owners and management. In the same spirit, newly established firms were expected to exhibit high performance as they were established by new owners with a focus on core competence and profits. In this spirit we analyze how the financial outcomes of firms are linked to working capital and the cost of labor.

Our paper is therefore related to two strands of literature. First, we contribute to the literature examining the effects of ownership structure on firm performance in transition countries (see Boycko et al., 1996 for a theoretical treatment and Djankov and Murell, 2002; Morck et al, 2005; and Estrin et al., 2009 for empirical surveys). The actual literature almost uniformly suggests that privatization to foreign owners greatly increases efficiency. The effect of domestic ownership is largely also positive but not as much as the effect of foreign ownership. This is the case only for Central European economies. In CIS countries the effect of domestic ownership is insignificant or slightly negative (Estrin et al., 2009; Brown et al., 2006). In addition, these efficiency differences between domestic- and foreign-owned firms do not seem to diminish over time (see e.g., Blomstrom, 1988; Haddad and Harrison, 1993; 
Aitken and Harrison, 1999; Arnold and Javorcik, 2009; Estrin et al., 2009). ${ }^{1}$ Several studies examine the concentration of ownership and find that it plays an important role, with majority private ownership having mostly positive effects on productivity (Pivovarsky, 2003; Claessens and Djankov, 1999); the overall positive effect is again driven primarily by foreignowned firms. Finally, some studies suggest that de novo firms are more productive than or at least as productive as SOEs privatized to domestic owners (Sabirianova et al., 2005a). In contrast to the above review, the literature on firm efficiency in CEE countries is rather limited. Little is known about the technical efficiency of firms that underwent restructuring during the transformation process towards a market economy.

Second, our paper is related to the literature estimating technical efficiency. We employ the stochastic production possibility frontier approach introduced by Aigner et al. (1977) and Meeusen and van den Broeck (1977), and further adapted for panel data and timevarying technical efficiency by Khumbhakar (1990) and Battese and Coelli (1995). Although this methodology is well established in the empirical literature, there is still a lack of reliable empirical evidence on firm technical efficiency in post-transition economies. A few authors analyze this agenda for the pre-transition years, finding that there is substantial variation between highly efficient firms and firms that can still achieve considerable efficiency gains. For instance, Brada and King (1994) analyzed the efficiency of firms in Poland. Brada et al. (1994) estimated the efficiency of Czechoslovak and Hungarian firms in the early 1990s using frontier production functions. They computed the average efficiency level for different sectors and found that this level varies between $40-80 \% .^{2}$ In addition, they found that the efficiency is positively related to the size of the firm. This implies that economic reforms could improve the technical efficiency of firms substantially. In addition, the authors test whether firm characteristics affect technical efficiency. As a result firm size and profitability was found to be positively related to efficiency whereas ownership had no significant effect. Methodologically, Brada et al. (1994) stress that technical efficiency can be measured independently of firms' profit (or output) maximization objectives and measures of technical efficiency facilitate comparison across economic systems. Measuring allocative efficiency, which is based on selecting the mix of inputs that generates the least-cost production, therefore remains problematic given the periods of macroeconomic instability prevalent in most of the post-transformation economies.

\footnotetext{
${ }^{1}$ Some of these studies do not control for possible selection effects when foreign owners purchase only the most productive firms. However, even after controlling for such effects (Estrin et al., 2009), the difference between domestic- and foreign-owned firms remains large and persistent.

${ }^{2}$ Indeed, most of the authors using the stochastic production possibility frontier approach compute average efficiencies across sectors. This approach was mainly used in agricultural economics (see Coelli, 1995 for a survey).
} 
Further, Konings and Repkin (1998) estimated the efficiency of firms in Bulgaria (1993-1995) and Romania (1994-1995) using firm-level data. They used firm size (market share) and profitability (profit margin) to explain firm efficiency in the two countries. The technical efficiency of firms was found to vary significantly both within and across industrial sectors in each country. The findings also suggest that in the course of transition, firm behavior becomes more diverse, which results in an increase in the variation of firms' efficiency levels within industrial branches. The results also support the hypothesis of Ickes and Ryterman (1993) that in a Soviet-type economy dominated by large heavy-industrial enterprises, efficiency levels would be high due to increased control and the assignment of better managers.

Sabirianova et al. (2005b) investigate whether firms near the efficiency frontier benefit from implementing development policies. The authors use 1992-2000 panel data on industrial firms in the Czech Republic and Russia to estimate a translog production function on panel data from medium and large firms in the two economies. They estimate the average efficiency level rather than the individual levels and their specification contains rather simple categories of ownership (the categories include private domestically owned; state, including federal, regional and municipal; mixed and foreign). They find that domestic-owned firms have not been converging to the technological frontier set by the most efficient foreign-owned firm. Moreover, this gap increased in the short term and was stable in the medium term.

Linz and Rahkovsky (2009) provide a systematic analysis of the level of and industry variation in technical inefficiency at the beginning of Russia's transition period by estimating a stochastic frontier production function for eleven industries with inefficiency effects related to ownership, export experience, and location in Moscow. The firms from eleven industries are grouped into three categories: heavy, light, and other industry. Their results generally support the proposition that non-state ownership improves efficiency, but the ownership effect varies by industry and over time. The authors reject the hypothesis that export experience increases efficiency during the initial stage of Russia's transition, and this result is especially strong in 1995.

Studies targeting the early stage of the transformation frequently use small and often unrepresentative samples of firms, often combine data from different accounting systems, and only have access to limited data on firm ownership. As a result, they often treat ownership as a relatively simple categorical concept (e.g., private versus state or state versus foreign, domestic private outsider versus domestic private insider), and they are often unable to distinguish the exact extent of ownership by individual owners or even relatively homogeneous groups of owners. These shortcomings prevent many studies from providing 
accurate evidence on the effects of various ownership categories on technical efficiency. In this paper we advance the literature by systematically addressing issues related to the efficiency effects of ownership and by eliminating the earlier shortcomings. First, we use panel data on a large sample of medium and large firms in the Czech Republic that were privatized $^{3}$ as well as those established as new firms; they constitute the bulk of the country's economic activity. Second, we cover a five-year period when accounting rules conforming to the international standard (IAP) were already in place. Third, we develop a more systematic analytical framework for evaluating the financial efficiency effect of domestic versus foreign ownership, as well as the effect of various degrees of ownership concentration.

The paper is structured as follows. In Section 2 we present our methodological approach. Data is described in Section 3. Section 4 presents our empirical results and section 5 concludes.

\section{Modeling Strategy}

\subsection{Theoretical background}

In our analysis we employ the stochastic production possibility frontier approach introduced by Aigner et al. (1977) and Meeusen and van den Broeck (1977) and further adapted for panel data by Khumbhakar (1990) and Battese and Coelli (1995). The method measures technical inefficiency under single output production. More important, the methodology helps to explain firm-level differences in efficiency as a function of the number of explanatory variables as opposed to estimating the average efficiency relative to the "best practice" for a number of sectors.

The methodology of the stochastic frontier approach is developed in the following way. A firm has the production function

$$
y_{i}=f\left(x_{i} ; \beta\right)
$$

\footnotetext{
${ }^{3}$ A massive privatization program was administered in the Czech Republic in the first half of the 1990s under three different schemes: restitution, small-scale privatization, and large-scale privatization. The first two schemes began in 1990 and were important during the early years of the transition. Large-scale privatization, by far the most important scheme, began in 1991, was completed in early 1995, and allowed for various privatization techniques (auctions, tenders, direct sales, and free transfer). Most large- and many medium-sized firms were transformed into joint-stock companies and their shares were distributed through voucher privatization (almost one-half of the total number of all the shares of all joint stock companies were privatized in the voucher scheme), sold in public auctions or to strategic partners, or transferred to municipalities. The voucher scheme was part of the large-scale privatization process. Two waves of voucher privatization took place, in 1992-93 and 1993-94. Both waves were administered in the same manner and there were no differences in their set-up. During the scheme, a total of 1664 firms were privatized.
} 
that defines the technological link between inputs $(x)$ and the resulting output $(y)$ under theassumption that production is conducted in an efficient manner. Due to some degree of inefficiency, a firm potentially produces less than it might and its production function is

$$
y_{i}=f\left(x_{i} ; \beta\right) \cdot T E_{i} .
$$

The firm's technical efficiency $T E_{i}$ represents the ratio of observed output to maximum feasible output and lies within the interval $(0,1] ; T E_{i}$ is considered to be nonnegative since the firm's output is assumed to be positive. If $T E_{i}=1$ then the firm employs all inputs efficiently and achieves an optimal output. If $T E i$ is smaller than one then the firm experiences a degree of inefficiency in its production. Further, two assumptions are made. One, efficiency is a stochastic variable with a distribution common to all firms and can be written as $T E_{i}=\exp \{-$ $u_{i t}$; ; since $0<T E_{i} \leq 1$, then $u_{i t} \geq 0$. Two, the firm's output is also subject to various random shocks that encompass anything from bad weather to unexpected luck and these effects are denoted as $\exp \left(v_{i t}\right)$. Thus, the production function is further expanded to

$$
y_{i}=f\left(x_{i} ; \beta\right) \cdot \exp \left(-u_{i t}\right) \cdot \exp \left(v_{i t}\right)
$$

After taking the natural log of both sides we obtain

$$
\ln y_{i t}=\beta_{0}+\sum_{j=1}^{k} \beta_{j i t} \ln x_{i t}+v_{i t}-u_{i t}
$$

In this general specification $v_{i t}$ is a pure noise component and a two-sided normally distributed variable, while $u_{i t}$ is the nonnegative technical inefficiency component. Both terms form a compound error term with an a priori unknown distribution. The model is estimated by maximum likelihood assuming a log-quadratic production function that encompasses the Cobb-Douglas specification and represents a less restrictive production function.

\subsection{Empirical approach - First stage}

We assess the determinants of firmfinancial efficiency in the following two-stage set-up. In the first stage we employ a Cobb-Douglas function to model firm output.The Cobb-Douglas production function is a convenient tool that is directly connected to the theoretical approach outlined earlier. From the empirical perspective Hájková and Hurník (2007) show that there is 
no significant difference between the total factor productivity growth estimated for Czech firms by Cobb-Douglas and by a more general production function. Moreover, quite a few authors examining the transformation effects in CEE and CIS countries argue that the CobbDouglas specification cannot be rejected (e.g., Brown et al., 2006; Brada et al., 1994).

The Cobb-Douglas function assumes that input elasticities and returns to scale are constant, and that the elasticities of substitution are equal to one. From the empirical perspective both assumptions are linked to the evidence that industries within the one-digit NACE division differ with respect to capital intensity, labor intensity, or technology intensity (Bjørnskov etal., 2009; Laafia, 2002). Therefore, we follow the mainstream of the literature and consider the interacting parameters of the Cobb-Douglas production function with twodigit NACE industries. As a result, in the specification below we consider different parameters of the Cobb-Douglas function for each two-digit NACE sector and this way we account for the specifics of a given sector. Formally, our model of the financial efficiency frontier of $i$ firms $(i=1, \ldots, I)$ in $J$ two-digit NACE sectors $(j=1, \ldots, J)$ over $T$ time periods $(t=$ $1, \ldots, t)$ is specified as follows:

$\ln y_{i t}=\sum_{j=1 \ldots J}\left[\beta_{0 j}+\beta_{1 j} \ln c_{i t}+\beta_{2 j} \ln l_{i t}\right] \cdot I D_{i t j}+\phi_{t}+v_{i t}-u_{i t}$

In specification (1) $\ln y_{i t}$ is the natural $\log$ of the value of the production of firm $i$ at time $t$, measured as firm turnover. Then $\ln c_{i t}$ is the natural $\log$ of the capital of each firm measured as working capital, and $\ln l_{i t}$ is the natural $\log$ of the firm's labor, measured as staff costs. $\beta_{0}$ is a common intercept for all firms. Working capital is the optimal proxy for the capital for our financial efficiency analysis. It is true that the money tied up in working capital is costly since it earns zero or a low rate of return (Kim et al., 1998). However, managing working capital efficiently stimulates growth opportunities and enables avoiding the costly interruptions of firms' day today operations (Ross et al., 2005). Hence, working capital is kept invested constantly with the purpose to secure the constant production of a firm, which is directly linked to its financial efficiency. A firm's capital can be understood as a proxy for the machinery used in production as input while staff costs directly proxy labor input.

$I D_{i j t}$ represents a vector of dummy variables to associate each firm with the specific industry sector $j$ it operates in. By the construction of the model we interact dummy variables for each of 45 two-digit NACE industries with both inputs (capital and labor) to control for industry-specific effects. In addition, we divide these industry sectors into six basic groups 
based on the different degrees of technology and knowledge intensity they represent (see Section 3 for details).

Further, it has been shown that ownership structures in firms are often industryspecific (see e.g., Demsetz, 1983 and Demsetz and Lehn, 1985 for theoretical evidence and Thomsen and Pedersen, 1998 for empirical evidence). Therefore, we employ industry-sector dummies in the first stage to capture the specific effects of various sectors so that these effects do not interfere with the ownership effects in the second stage. For the same reason we also include in specification (2) yearly time dummies $\left(\phi_{t}\right)$ that control for time-specific effects (country-wide economic development and business cycle) that are equal for all firms but vary over time. Finally, the random error is denoted as $v_{i t}$ as in (1) and $u_{i t} \geq 0$ represents financial inefficiency. Producer effects are required to be nonnegative because they represent the degree of financial inefficiency.

Specification (2) is based on the assumption that production technology changes over time as in the time-varying technical efficiency stochastic production frontier panel data model proposed by Cornwell et al. (1990) and Kumbhakar (1990). Inefficiency is formalized as $u_{i t}=\exp \left(-\eta\left(t-T_{i}\right)\right) u_{i}$, where $T_{i}$ is the last period in the panel of $i$ firms. Parameter eta $(\eta)$ enables distinguishing whether the efficiency increases or decreases over time. If $\eta>0$ the firm's efficiency increases over time, while efficiency decays if $\eta<0$. Because $t=T_{i}$ in the last period, the last period for firm $i$ contains the base level of inefficiency for that firm. If $\eta>0$, the level of efficiency increases toward the base level, and if $\eta<0$, the level of efficiency decays toward the base level. If there are no changes in technology, (in)efficiency remains the same over time $(\eta=0)$ and the time-varying model reduces to the time-invariant version. Under the time-invariant assumption the technical inefficiency parameter $u_{i t}=u_{i}$, where $u_{i}$ is iid-distributed $(\sim)$ according to a truncated-normal distribution that is truncated at zero with mean $\mu$ and variance $\sigma_{\mathrm{u}}^{2}\left(u_{i} \sim \mathrm{N}^{+}\left(\mu, \sigma_{\mathrm{u}}^{2}\right)\right.$. Then $u_{i}$ and $v_{i t}\left(v_{i t} \sim \mathrm{N}\left(\mu, \sigma_{\mathrm{v}}^{2}\right)\right.$ are distributed independently from each other and from the covariates in the model.

The above approach allows for efficiency to be influenced by factors outside the firm's control. We can distinguish random shocks that affect the production frontier (machinery breakdown, new policies affecting access to or utilization of inputs, etc.) from factors over which the firm has some control (workforce size, skill and effort, capital utilization, etc). The specification itself is estimated as a panel with fixed effects to alleviate the potential problem of the endogeneity of firm ownership with respect to efficiency. During the estimation stage we formally test for a correct first stage specification, e.g., whether to use the time-invariant or time-varying efficiency model. 


\subsection{Empirical approach - Second stage}

Ownership structures have been identified in numerous relevant studies as a key determinant of firm performance (see Estrin et al., 2009 for a general overview and Hanousek et al., 2007a, 2009 for specific results related to Czech firms). Therefore, in the second stage we model how firm efficiency $\left(u_{i}\right)$ is determined by its ownership structure: $\left(u_{i}\right)=f$ (ownership structure); a formal model is introduced later in this section. Specifically, we aim to answer the questions, formulated as hypotheses that appear below.

The literature examining the agency problem arising from the separation of ownership and control often argues that managers might follow other goals than the owners would like. Because of this a concentrated ownership structure might lead to higher firm efficiency since it results in the superior monitoring of managers (Shleifer and Vishny, 1997; Hill and Snell, 1989). Therefore we expect that there will be a positive relationship between ownership concentration and efficiency. As pointed out above we are able to identify all owners with ownership stakes of at least 10 percent; sometimes, but definitely not as a rule, we are able to indentify dispersed ownership of less than $10 \%$. Therefore, we are able to test whether the baseline relationship between ownership concentration and efficiency holds and formulate a baseline hypothesis:

Hypothesis 1: A majority owner reduces a firm's inefficiency.

Empirical works show that majority owners can change their attitude when a strong minority owner is present in the firm, for example in the case of dividend payments (Gugler,2003). We speculate that a majority owner, when confronted with a strong minority owner, might also affect a firm's financial efficiency. This leads to our second hypothesis:

Hypothesis 2: Majority owners, when confronted with strong minority owners, reduce a firm's inefficiency more compared to uncontested majority owners.

The findings of agency theory indicate that control is a very good mechanism to assure that managers work to help owners. In other words, dispersed and/or minority ownership should not improve a firm's efficiency as control is very likely to be missing in such an ownership structure. On the other hand, in the presence of highly dispersed ownership, even a minority owner with a sufficiently high stake is able to control a firm; for example, La Porta et al. (1999) employ $20 \%$ as a threshold for control of a company. Control can be exerted to ensure that managers fulfill their duties. Our data allows us to test the link between control and efficiency as we are able to identify dispersed ownership as well as monitored and/or controlling minority ownership. Based on this reasoning we formulate the following two hypotheses:

Hypothesis 3: Minority and dispersed ownership both reduce a firm's inefficiency. 
Hypothesis 4: Minority owners in the presence of highly dispersed remaining ownership reduce a firm's inefficiency.

Further, in the trade literature it has been argued that foreign owners have better access to technology and therefore firms owned by foreigners should be more efficient (Temouri et al., 2008; Blomström et al., 2001). Hence, existence of the technological gap between foreign and domestic owners has become a stylized fact in the applied trade literature. Based on this we formulate the next hypothesis:

Hypothesis 5: A foreign owner reduces a firm's inefficiency.

The economic convergence literature usually analyses various types of convergence on the macroeconomic level (Barro, 1991; Bernard and Durlauf, 1995; Ben-David, 1996). However, the origin of the aggregated macroeconomic outcomes has to be sought on the micro level. For a considerable period of time, domestic and foreign owners were both present in the Czech economy through their property stakes in firms and corporations. They interacted through business activity as well as through various technology transfers (Kosová, 2009). Following this line of reasoning we formulate our final hypothesis:

Hypothesis 6: There exists a convergence in the contribution to a firm's efficiency between domestic and foreign owners.

We aim to test the above hypotheses by employing a model that links firm efficiency with ownership structure. The model for each year (period $t$ ) is specified as follows:

$$
u_{i}=\alpha+\sum_{j=1}^{J} \delta_{j} O W N_{i}^{j} \quad \text { for all } i=1, \ldots \mathrm{N}
$$

The ownership structure $\left(O W N_{i}^{j}\right)$ is defined for each firm $i$ to distinguish a specific ownership category $j$. We distinguish domestic- and foreign-owned private firms based on exact knowledge of the owner's origin. If there is missing information on the owner's domicile we introduce a special category of "unknown" domicile, so we consider the categories of domestic, foreign, and unknown-domicile owners. From our data we can also distinguish the extent of ownership concentration along with the extent of control over a firm. Following the country- and legal-specific approach of Hanousek et al. (2007a), we construct ownership categories to distinguish majority owners (stake above 50\%), monitoring owners, minority owners (stake above 33\%), and dispersed ownership. We elaborate more on the ownership categories in the data section.

To conclude, specification (4) recognizes that ownership structure affects firm efficiency. In the trade literature it is usually argued that only very productive firms are able to 
be internationally active (Melitz, 2003). As these firms have acknowledge advantage the foreign-owned firms are able to increase their efficiency via spillovers. Moreover, it is likely that foreign owners have more experience in the business environment as well as better access to superior technologies (Temouri et al., 2008). This can result in better efficiency. Another explanation of the productivity gap between foreign- and domestic-owned firms could be differential access to external credit (Gorodnichenko and Schnitzer, 2010). This reason is largely absent in the case of the Czech Republic, though. Access to external financing was relatively easy before banks were fully privatized and banking privatization was achieved by 2001 (Hanousek at al., 2007b). After EU accession in 2004 the frictions on the lending market were largely absent as the country complied with acquis communautaire.

Specification (4) is estimated as a cross-section for a sequence of years (time periods $t) .{ }^{4}$ Based on the estimates obtained from (4) we are able to test our hypotheses that link firm efficiency with firm ownership.

\section{Data}

We develop a model to examine the impact of ownership structure on firm financial efficiency in the Czech Republic. We employ firm-level unbalanced panel data for the period 1996-2007 from the Amadeus database. Depending on the specific year, we have firm-level balance sheet data (turnover, working capital, and staff costs) for 3,818 to 87,268 firms. As these are multiproduct firms we are unable to obtain exact information about the quantities (input, output) connected with the production process of each product of a firm. For this reason we follow the standard approach in the literature and employ financial variables from firms' balance sheets (see Coelli et al., 2005 for an overview). We further combine the balance-sheet data with ownership data obtained from the Amadeus, Aspekt, and Čekia databases. Altogether we work with a unique firm-level panel data of more than 400,000 firm/year observations for the period 1996-2007.

Descriptive statistics for all of the variables are presented in Table 1. The number of firms increases dramatically from 1996 on, confirming our argument in Section 1 that early studies relying on unrepresentative samples could not deliver accurate results. Further, since our data set is constructed from several editions of the Amadeus database, we include in our data set also firms that might disappear from more recent editions. This way we minimize selection and survival biases. The mean values of all the variables are in natural logarithms.

\footnotetext{
${ }^{4}$ This estimation approach was chosen for the following reason. Assume a highly efficient firm with an ownership structure that is rigid, e.g., it does not change over time or at least is quite stable. If specification (4) is estimated as a panel with fixed effects, then we would not be able to estimate effect of ownership on efficiency because rigid ownership would be included in the fixed effect. Since we want to avoid precisely this, we opt for the sequential estimation of cross-sections.
} 
As can be seen from the values of the mean of working capital as well as staff costs, more and more of the smaller firms enter our dataset as time progresses. This is in accord with the values for turnover, which decrease with time as well.

In the first stage we derive firm efficiency based on the two-input (capital, labor) Cobb-Douglas production specification introduced in Section 2. We use turnover to measure the production of each firm and as inputs we employ working capital (capital) and staff costs (labor). ${ }^{5}$ In specification (2) we include annual time dummy variables serving as a deflator of our financial variables in the same manner as Sabirianova et al. (2005a). As firm efficiency might be industry-specific (Pavitt, 1984), we include industry sectors as a vector of explanatory variables as well. Industry sectors are identified according to the two-digit NACE category. In order to capture different effects across sector-specific intensities we follow the approach of Laafia (2002), who divides industries into different sectors based on their technology and knowledge intensity. This approach is based on the Eurostat official industrial-sector aggregations. Hence, following the official Eurostat methodology we define several groups of industries in manufacturing and services to reflect the different degrees of technology and knowledge they represent. In manufacturing industries we have four groups: high technology, medium-high technology, medium-low technology, and low technology. In service industries we have five groups: knowledge-intensive services (KIS), high-tech KIS, market KIS (excluding financial intermediation and high-tech services), less-knowledgeintensive services (LKIS), and market LKIS. Tables1.A and 2.A in the Appendix provide an overview of the development of the financial variables in firms across these sectors. The firms that achieve the best results in terms of highest turnover are medium-high and low technology firms in the manufacturing sector and LKIS and market LKIS firms in the service sector. Further, Table 3.A contains a list of all the NACE two-digit industries grouped into sectors according to the official Eurostat methodology. In this table we also show in great detail how firms are distributed according to the sector they belong to and the proportion of firms belonging to a specific sector with respect to the total sample.

In Table 2 we provide descriptive statistics across the manufacturing and service groups defined above. The table indicates that approximately two thirds of our firms are from the service sector. The number of firms dramatically increases irrespective of whether the firm

\footnotetext{
${ }^{5}$ In order to show that our results are robust to the use of different input proxies we estimate the Cobb-Douglas function with total assets, fixed assets, and total capital as proxies for capital and number of employees as a proxy for labor. Note that staff costs and number of employees are close measures of labor intensity since within a given industrial sector we can expect a relatively stable wage distribution as shown by Krueger and Summers (1988) as well as Crinò (2005) specifically for Poland, Hungary, and the Czech Republic. We prefer to use staff costs because only for a small number of firms is the number of employees available; plus for the period 19961997 we have no records on number of employees.
} 
is in the service or manufacturing sector. However, the largest increase can be observed in the low-tech manufacturing sector and less knowledge-intensive services. The values of turnover, staff costs, and capital indicate that more and more smaller firms enter our data as time progresses. We can observe such changes in both the manufacturing and service sectors.

In the second stage we examine the impact of the ownership structure on estimated efficiency. Ownership type and concentration has been recognized as an important determinant of firm performance in developed economies (Temouri et al., 2008; Hill and Snell, 1989) as well as emerging economies (Estrin et al., 2009; Pivovarsky, 2003). We define the ownership variables with respect to country-specific legal rules as argued in Gugler (2003). Following Hanousek et al. (2007a) we define several ownership variables to reflect different concentration thresholds based on the country's legal rules. Depending on their stakes, different blockholders have under Czech law different opportunities to influence corporate governance. In particular, the law provides important rights of ownership and control to owners with majority ownership (more than $50 \%$ of shares), blocking minority ownership (more than $33 \%$ but not more than $50 \%$ of shares) and what we define as legal minority ownership (at least 10 but not more than 33\%of shares). Majority ownership grants the owner the right to staff management and supervisory boards, alter and transfer firms' assets and make crucial strategic decisions at general shareholder meetings. Through management and supervisory boards, majority ownership also facilitates more direct executive control of the company. Blocking minority ownership gives the right to block a number of decisions, such as those related to increasing or reducing assets and implementing major changes in business activities that the majority shareholder can try to implement at a general shareholder meeting. Finally, legal minority ownership is potentially important because the law entitles the holder of this stake to call a general shareholder meeting and obstruct decisions by delaying the implementation through lengthy court proceedings. Effective legal minority shareholders (including the state) may thus use their ownership position to delay or completely block the implementation of decisions by stronger shareholder(s).

Majority and blocking minority ownership represent different degrees of concentrated ownership, while legal minority ownership can be viewed as a form of moderately dispersed ownership. Highly dispersed ownership arises when the stake of the largest holder does not reach the legal (10 percent) minority. Based on the above definitions of ownership concentration, we define several specific ownership categories. Rather than using exact percentage stakes, we opt for dummy variables that differentiate various ownership categories and allow us to provide more comprehensive results. All ownership categories are exclusively 
defined and they are also distinguished for domestic and foreign owners, as well as those without a known domicile.

Majority ownership is a dummy variable that is coded 1 when an owner holds more than a $50 \%$ stake in a firm and otherwise there is only dispersed ownership; it is coded 0 otherwise. This category provides the majority owner with effective control over the company.

Monitored majority ownership is a dummy variable that is coded 1 when there is majority ownership in a firm but at the same time there exists at least one minority owner with a stake higher than $10 \%$; it is coded 0 otherwise. This ownership category reflects the situation in firms where the majority owner is often confronted with at least one non-marginal owner pursuing its own interest.

There are two minority-category variables. First, controlling minority ownership is a dummy variable that is coded 1 when an owner holds a stake in a firm that is greater than $10 \%$ and this stake is greater than the sum of all the remaining stakes that can be identified, e.g. the remaining stakes of all the listed companies. It is coded 0 otherwise. This is an extreme case of control provided through a minority stake in a company with highly dispersed ownership. It is a realistic category as in numerous companies dispersed ownership prevents the emergence of larger stakes. This category has two implications relevant for our analysis. One, at general shareholder meetings dispersed owners would have to act in concert to override the decision of the single controlling minority owner. Two, according to the law, shareholders have to disclose their identities in order to commonly execute shareholder rights by agreement. In this case, their identities would be revealed and listed in the registry, and the database would contain the ownership identities of highly dispersed owners.

Combined controlling minority ownership is the second minority category that is coded 1 when there are two owners whose combined stake exceeds $50 \%$ and 0 otherwise. These two owners cannot individually control the firm or act against each other as individually they do not have enough voting power. However, they can (but don't have to) coordinate their steps and control the company via combined voting rights, which give them a majority.

Dispersed ownership is a dummy variable that is coded 1 when all owners hold stakes smaller than $10 \%$ in the firm and there is no majority or minority owner); it is coded 0 otherwise.

As noted earlier, we are able to distinguish domestic and foreign owners for a many of the firms in our data set. However, for all the categories defined above we introduce additional dummy variables to capture the ownership when the owner's domicile cannot be 
identified. Either an owner is listed in the database without a country code identifying its domicile, or a firm has a legal structure that prevents distinguishing between domestic and foreign owners; e.g., a firm with unregistered stocks. Finally, a constant captures unknown ownership of a firm. In this case the firm either exhibits highly dispersed ownership or does not report on its ownership.

\section{Empirical Results}

Results from the first stage are presented in Table 2. By employing a likelihood ratio test we formally test for the efficiency frontier specification and based on the results we opt for the time-invariant efficiency frontier model. The contribution of capital and labor to firm production differs as the coefficient associated with labor is uniformly larger than that of capital. This finding indicates that firms are on average more labor-intensive. Further, we also formally tested whether the sum of the coefficients associated with both inputs is statistically different from unity; this would indicate constant returns-to-scale production. The results of these tests show that the sum of the coefficients is smaller than one (about 0.8 on average), a level indicating decreasing returns-to-scale (DRS). Hence, we can conclude that larger firms exhibit lower efficiency. In Tables 4.A and 5.A in the Appendix we present the first-stage results in much greater detail across the manufacturing and service sectors introduced in Section 3. In general, the pattern of the DRS found in Table 2 remains the same at this detailed level, but there are two exceptions. Sector 34 (manufacture of motor vehicles, trailers, and semi-trailers) exhibits constant returns-to-scale (CRS) with the coefficients' sum being 1.004. Sector 35 (manufacture of other transport equipment) exhibits increasing returns-toscale (IRS) with the coefficients' sum being 1.142. We attribute this finding to advances in technology brought into the Czech automotive industry, which has been rapidly developing over the past years.

First, in Table 3 we present the results of the determination of efficiency by ownership category without distinguishing among the technology- or knowledge-intensive sectors in which firms operate. We present the ownership concentration categories in the left column. Each subsequent column then contains coefficients for the distance from the efficiency frontier for a specific ownership category and specific year. Coefficients are presented as fullset-of-dummies coefficients and should be interpreted in the following manner. A fully efficient firm would have a distance from the efficiency frontier equal to zero. Hence, the larger the value of a statistically significant coefficient associated with an ownership category, the further the category's distance from the efficiency frontier. Hence, a particular type of ownership category is associated with lower contribution to firm efficiency. In other words, 
positive coefficients closer to zero are associated with a greater impact of a specific ownership category on firm efficiency. Differences in coefficients' values over time are due to changes in our data set: firms with a specific ownership structure enter and leave the data set and ownership structure changes over time. Further, the composition of firms changes: more and more small and medium firms are included in the data set and they also bring larger fluctuations in their financial balances. However, we estimate financial efficiency with firmspecific fixed effects and we also account for economic trends by having annual dummies in specification (2). Hence, the coefficients presented in Table 3 (as well as in Tables4 and 5) should capture the true effect of the specific ownership category.

Majority ownership exhibits on average a strong impact on firm efficiency because coefficients are consistently small (ranging from 0.041 to 0.132 ) and below the values for most other ownership (concentration) categories. This result is in accord with agency theory. Further, we can see that the coefficient values associated with foreign owners are slightly smaller (coefficient range 0.044 to 0.124 ) than those of domestic shareholders (coefficient range 0.041 to 0.132 ). Hence, foreign owners contribute to a firm's efficiency to a somewhat larger degree than domestic owners. The differences in coefficients between oreign and domestic owners vary with time due to the unbalanced nature of our panel and are more pronounced during the late 1990s. However, the differences disappear after 2004, hinting at a convergence in corporate governance as well as in other aspects between foreign- and domestic-controlled firms. As the date coincides with the accession to the European Union, the fact that the difference disappears hints at the disciplining effect of this event. In those firms where the domicile of the majority owner is unknown, the financial efficiency is by far the poorest of all the remaining categories. In these firms we also do not know the type of legal entity on top of the unknown domicile. This is a perfect proxy for non-transparent ownership that is associated with low efficiency. Inefficiency means that either the firm is poorly managed or financial efficiency is not a primary goal and the low efficiency might even be achieved on purpose.

In firms where a majority owner is confronted with the presence of a minority owner or owners the ownership structure is conducive to the firm's efficiency in general. This monitored majority helps to improve firm efficiency especially when the majority owner is of domestic origin as coefficient values are consistently smaller (coefficient range 0.023 to 0.091) than the values associated with foreign owners (coefficient range 0.094 to 0.219).However, there is a lack of statistically significant coefficients for half of the years in 
the case of foreign owners. ${ }^{6}$ Further, the monitored domestic majority category correlates with firm efficiency at a better level than a simple domestic majority. This finding is important as it hints at a positive disciplining effect with respect to firm efficiency when a majority owner must account for the presence of an influential minority shareholder. It also has a straightforward implication for corporate governance as it resembles the composition of a board of directors where some positions are staffed by independent outside directors.

Minority owners whose stakes are still larger than combined stakes of the rest of the known owners also contribute to firm efficiency but the effect of minority ownership is less conclusive for foreign owners due to statistically insignificant coefficients. Further, domestic minority owners impact firm efficiency to a greater degree (coefficient range 0.027 to 0.105 ) than foreign owners (coefficient range 0.044 to 0.176). This is a similar pattern as with monitored majority owners. The differences between the extents of the impact are much smaller, though. In any event, these results also show that ownership concentration enabling even weakly grounded control tends to bring better results than purely dispersed ownership.

Minority owners whose combined shares provide them with a majority of the voting rights-controlling minority ownership - are a special ownership category in terms of contribution to firm efficiency. In general, statistically significant coefficients are associated with domestic owners as coefficients associated with foreign ownership lack significance. The consistently smallest coefficients (ranging from 0.013 to 0.049 ) indicate that this ownership category is more conducive to firm efficiency than other categories discussed above. The reason might stem from the fact that two minority owners face the situation where neither of them can fully control the company and only their coordinated steps would enable them to jointly control the company. The inability to fully control a firm by one of the two minority owners resembles a "Mexican standoff". This slang term defines a stalemate or a confrontation that neither of the parties can win. To come out of the deadlock the parties must resolve the situation by negotiation, surrender, or attack. The consistently very low values of the coefficients associated with domestic owners hint at a peaceful use of power between the two minority shareholders and a contributing effect of this ownership arrangement with respect to firm efficiency. Alternatively, firms can be established from the beginning as having cooperating co-owners, so a deadlock is averted.

Finally, dispersed ownership is intuitively a problematic category to judge. Lack of statistically significant coefficients and their relatively large values do not allow for an easy

\footnotetext{
${ }^{6}$ Lack of statistical significance can also mean that the category of monitored majority foreign ownership during the period 1996-2000 contains the most efficient firms as the coefficients are close to zero. The reason is that when we assess our hypotheses in effect we test that the coefficient equals zero. In the case of a very small and statistically insignificant coefficient we are unable to reject the hypothesis that the distance from the efficiency frontier equals zero.
} 
evaluation. However, dispersed ownership does not seem to be conducive to improving firm efficiency as the few statistically significant coefficients are quite large. The same results apply to the ownerships we are unable to identify, which are captured by a constant, where mostly very large coefficients are found.

Further, in Tables 4 and 5 we present results that distinguish ownership effects depending on the economic sectors firms operate in. We distinguish four manufacturing sectors based on technology levels (Table 4) and five service sectors based on the knowledge intensity they represent (Table 5). As mentioned in Section 3, this division strictly adheres to the methodology of Eurostat.

From Table 4 we can see that on average the owners of firms belonging to the medium-low- and low-technology sectors are most conducive to firm efficiency. Then, in these sectors, domestic monitored-majority owners tend to be associated with the highest financial efficiency in the firms they control. It is also interesting to note that minority domestic owners who are able to exert control over firms because the rest of the ownership is dysfunctionally dispersed exhibit a comparably high degree of efficiency in firms across all four sectors. Even more interesting is the fact that firms belonging to opposite technologybased edges (high- and low-technology sectors) exhibit equal and very good results. Finally, coalitions of two minority owners with the ability to jointly control firm drive efficiency in medium-low- and low-technology sectors and by this token they accord with the general pattern.

The results for firms operating in services are presented in Table 5. On average the owners of firms belonging to the sectors of less-knowledge-intensive services (LKIS) and market LKIS are most conducive to firm efficiency. On the contrary, firms in the sectors of KIS and market KIS exhibit exceptionally poor results that are witnessed by rather high coefficients. Finally, firms in high-tech KIS do quite well with majority and monitoredmajority foreign owners, driving the best efficiency results, while other categories offer a similar degree of efficiency irrespective of the owner's domicile.

\section{Conclusion}

We analyze the evolution of financial efficiency in Czech firms during the period 1996-2007 and how financial efficiency is determined by ownership structure. We provide evidence that ownership structure matters quite a lot and indicate numerous detailed results. Highly concentrated ownership is consistently beneficial to firm efficiency and this finding is in favor of agency theory. Not surprisingly, dispersed ownership is the least preferable option. 
On top of these more or less expected results we show that a simple majority is not necessarily the best structure to improve financial efficiency. A majority owner monitored by a strong minority owner (monitored majority) is more conducive to firm efficiency than a pure majority. Further, we find that cooperative coalitions of minority owners that allow for control in a firm bring superior results. Minority owners who share control in a firm may endup rivaling each other, which is not conducive to efficiency. However, our evidence points out that minority owners do cooperate and improve the financial efficiency of their firms.

We also show that financial efficiency is higher in less technology-demanding and less-knowledge-intensive firms. This finding may question to some extent the advancements of the Czech economy. On the other hand we find that after 2004, financial efficiency converges between domestic and foreign (majority) owners. This is certainly a positive feature hinting at improved management and corporate governance in Czech firms. 


\section{References}

Aigner, D., Lovell, C., \& Schmidt, P. (1977). Formulation and estimation of stochastic frontier production functions. Journal of Econometrics, 6, 21-37.

Aitken, B. J. and Harrison, A. E. (1999). Do domestic firms benefit from direct foreign investment? Evidence from Venezuela. American Economic Review 89(3), 605-618.

Arnold, J. M. and Javorcik, B. S. (2009). Gifted kids or pushy parents? Foreign direct investment and plant productivity in Indonesia? Journal of International Economics79(1), 42-53.

Barro, R. J. (1991). Economic Growth in Cross-Section of Countries. Quartely Journal of Economics, 106(2), 407-443.

Battese, G., \&Coelli, T. (1995). A model for technical inefficiency effect in a stochastic frontier production function. Empirical Economics, 20, 325-332.

Ben-David, D. (1996). Trade Convergence Among Countries. Journal of International Economics, 40(3-4),279-298.

Bernard, A. B. and Durlauf, S. N. (1995). Convergence in International Output. Journal of Applied Econometrics, 10(2), 97-108.

Bjørnskov, C., Philipp Meinen, JørgenUlff-Møller Nielsen and Philipp J.H. Schröder, 2009. Lobbying for anti-dumping measures: Does distance from Brussels matter? Working paper, Department of Economics, Aarhus University

Boycko, M., Shleifer, A. and Vishny, R. W. (1996). A theory of privatization. Economic Journal 106(435), 309-319.

Blomström, M. (1988): Labor productivity differences between foreign and domestic firms in Mexico. World Development 16(11), 12951298.

Blomström, M., Globerman, S., and A. Kokko (2001). The Determinants of Host Country Spillovers from Foreign Direct Investment. In N. Pain (ed.), Inward Investment, Technological Change and Growth. Basingstoke: Palgrave.

Brada, J., King, A. (1994). Differences in the technical and allocative efficiency of private and socialized agricultural units in pre-transformation Poland. Economic Systems, 18(4), 363-376.

Brada, J., King, A. and Ma, C. (1994). Industrial economics of the transition: determinants of enterprise efficiency in Czechoslovakia and Hungary. Oxford Economic Papers, 49, 104-127.

Brown, J. D., Earle, J. S and Telegdy, Á. (2006). The productivity Effects of Privatization: Longitudinal Estimates from Hungary, Romania, Russia, and Ukraine. Journal of Political Economy 114(1), 61-99.

Coelli, T.J. (2005). Recent Developmentsin FrontierModelling and EfficiencyMeasurement.Australian Journal ofAgricultual Economics 39(3), 219-45.

Cornwell, C., Schmidt, P. and Sickles, R. C. (1990) Production Frontiers with Cross-

Sectional and Time-Series Variation in Efficiency Levels, Journal of Econometrics 46: 185-200.

Claessens, Stijn, and Simeon Djankov. 1999. "Ownership Concentration and Corporate Performance in the Czech Republic.” Journal of Comparative Economics 27(3): 498513.

Coelli T., PrasadaRao D.S. and G. E. Battese, 2005. An Introduction to Efficiency and Productivity Analysis, Kluwer Academic Publishers. 
Crinò, R. (2005). Wages, Skills and Integration in Poland, Hungary and the Czech Republic: an Industry-Level Analysis, Transition Studies Review, 12, 432-45.

Demsetz, H. (1983). The Structure of Ownership and the Theory of the Firm. Journal of Law and Economics, 16, 375-390.

Demsetz, H., and Lehn, K. (1985). The Structure of Corporate Ownership: Causes and Consequences. Journal of Political Economy, 93, 1153-1177.

Djankov, Simeon, and Peter Murrell. 2002. "Enterprise Restructuring in Transition: A Quantitative Survey.” Journal of Economic Literature, 40(3): 739-92.

Estrin, S., Hanousek, J., Kočenda, E., Svejnar, J., 2009. Effects of Privatization and Ownership in Transition Economies. Journal of Economic Literature, 47(3), 699-728.

Gorodnichenko, Y. and Schnitzer, M. (2010), Financial constraints and innovation: Why poor countries don't catch up. Working Paper 15792. National Bureau of Economic Research, Cambridge, MA

Gugler, K., 2003. Corporate Governance, Dividend Payout Policy, and the Interrelation between Dividends, R\&D, and Capital Investment. Journal of Banking and Finance 27, 1297-1321.

Haddad, M. and Harrison, A. E. (1993). Are there positive spillovers from direct foreign investment?: Evidence from panel data for Morocco, Journal of Development Economics 42(1), 51-74.

Hájková, D. and Hurník, J. (2007). Cobb-Douglas Production Function: The Case of a Converging Economy. Czech Journal of Economics and Finance, 57 (9-10), 465-476.

Hanousek, J., Kočenda, E. and Svejnar, J. (2007a). Origin and concentration: Corporate ownership, control and performance in firms after privatization. Economics of Transition 15(1), 1-31.

Hanousek, J., Kočenda, E., Ondko, P., (2007a). The Banking Sector in New EU Member Countries: A Sectoral Financial Flows Analysis. Czech Journal of Economics and Finance, 57(5-6), 200-224.

Hill, W. L. and Snell, S. A. (1989). Effects of Ownership Structure and Control on Corporate Productivity. The Academy of Management Journal, 32(1), 25-46.

Ickes, B., and Ryterman, R. (1993). Entry without exit: economic selection under socialism. Pennsylvania State - Department of Economics Papers No. 10-93-4a.

Kim, C., Mauer, D. C. and Sherman A. E. (1998). The determinants of corporate liquidity: theory and evidence. Journal of Financial and Quantitative Analysis, 33(3), 335-359.

Konings, J., Repkin, A. (1998). How efficient are firms in transition countries? Firm-level evidence from Bulgaria and Romania. Transition Economics, No.1839, 1-26.

Kosová, R. (2009). Do Foreign Firms Crowd Out Domestic Firms? Evidence from the Czech Republic. The Review of Economis and Statistics, 92 (4), 861-881.

Krueger, A. B. and L. H. Summers (1988). Efficiency Wages and the Inter-Industry Wage Structure, Econometrica, 56(2), 259-293.

Khumbhakar, S.C., 1990. Production Frontiers, Panel Data, and Time-Varying Technical Inefficiency. Journal of Econometrics 46: 201-211.

Laafia, I. (2002). Employment in High Tech and Knowledge Intensive Sectors in the EU Continues to Grow in 2001. Eurostat, Statistics in Focus: Science and Technology 9(4), 1-8.

La Porta, Rafael, Florencio Lopez-de-Silanes, and Andrei Shleifer, 1999, Corporate ownership around the world, Journal of Finance 54, 471-517. 
Linz, S., Rahkovsky, I. (2009). Analyzing the technical efficiency of Russian firms: 19921995. (April 27, 2009). Available at SSRN: http://ssrn.com/abstract=1395803

Meeusen, W., van den Broeck, J. (1977). Efficiency estimation from Cobb-Douglas production functions with composed error. International Economic Review, 18(2), 435-444.

Melitz, M. J., (2003). The Impact of Trade on Intra-Industry Reallocations and Aggregate Industry Productivity. Econometrica 71 (6), 1695-1725.

Morck, R., Wolfenzon, D., Yeung, B. 2005. "Corporate Governance, Economic Entrenchment, and Growth." Journal of Economic Literature, 43(3): 655-720.

Pavitt, K., (1984). Sectoral patterns of technical change: towards a theory and a taxonomy. Research Policy 13, 343-373.

Pivovarsky, A. (2003). Ownership Concentration and Performance in Ukraine's Privatized Enterprises. IMF Staff Papers 50(1), 10-42.

Ross, S. A., Westerfield, R. W. and Jeffrey, J. (2005), Corporate Finance, $7^{\text {th }}$ International edition; McGraw Hill.

Sabirianova Peter, K., Svejnar, J. and Terrell, K. (2005a). Foreign Investment, Corporate Ownership, and Development: Are Firms in Emerging Markets Catching up to the World Standard? IZA DP1457.

Sabirianova Peter, K., Svejnar, J. and Terrell, K. (2005b). Distance to the efficiency frontier and foreign direct investment spillovers. Journal of the European Economic Association, 3(2-3), 576-586.

Shleifer, Andrei, and Robert W. Vishny. 1997. A Survey of Corporate Governance. Journal of Finance, 52(2): 737-83.

Temouri, Y., N.L. Driffield and D.A. Higón, 2008. Analysis of productivity differences among foreign and domestic firms: Evidence from Germany, The Review of World Economics, 144(1), 32-54.

Thomsen, S., and Pedersen, T. (1998). Industry and ownership structure. International Review of Law and Economics, 18, 386-404. 
Table 1: Simple descriptive statistics (all variables are in logs)

\begin{tabular}{c|cccr}
\hline \hline Year & Turnover & Working capital & Staff costs & $\begin{array}{c}\text { Number of } \\
\text { firms }\end{array}$ \\
\hline \hline 1996 & 15.06 & 9.39 & 13.04 & 3818 \\
1997 & 14.78 & 9.25 & 12.81 & 4335 \\
1998 & 14.80 & 9.10 & 12.90 & 5248 \\
1999 & 14.57 & 8.97 & 12.65 & 6609 \\
2000 & 14.47 & 8.95 & 12.51 & 8301 \\
2001 & 14.32 & 8.82 & 12.40 & 11242 \\
2002 & 13.03 & 7.62 & 11.32 & 27032 \\
2003 & 12.74 & 7.15 & 11.06 & 44649 \\
2004 & 12.70 & 7.02 & 11.04 & 60238 \\
2005 & 12.40 & 6.93 & 10.79 & 72550 \\
2006 & 12.36 & 6.84 & 10.77 & 87268 \\
2007 & 12.55 & 6.96 & 10.94 & 79418 \\
\hline \hline
\end{tabular}

Table 2: First step - efficiency frontiers

\begin{tabular}{lrrr}
\hline \hline NACE Grouping & $\begin{array}{r}\text { Constant } \\
\text { term }\end{array}$ & $\begin{array}{r}\text { Log Working } \\
\text { Capital }\end{array}$ & $\begin{array}{r}\text { Log Staff } \\
\text { Costs }\end{array}$ \\
\hline \hline Manufacturing industries: & & & \\
High-technology & 13.026 & 0.163 & 0.683 \\
Medium-high-technology & 12.566 & 0.121 & 0.757 \\
Medium-low-technology & 12.561 & 0.101 & 0.772 \\
Low-technology & 13.255 & 0.135 & 0.694 \\
\hline Service industries: & & & \\
Knowledge-intensive services (KIS) & 13.500 & 0.123 & 0.662 \\
High-tech KIS & 14.068 & 0.111 & 0.629 \\
Market KIS* & 13.388 & 0.127 & 0.670 \\
Less Knowledge-intensive services (LKIS) & 13.953 & 0.157 & 0.639 \\
Market services less KIS & 13.971 & 0.159 & 0.637 \\
\hline \hline
\end{tabular}

Notes: We use industry classification according to OECD-Eurostat as in Laafia 2002. The division is available at http://epp.eurostat.ec.europa.eu/cache/ITY_SDDS/Annexes/htec_esms_an2.pdf. The exact division as well as short description of each NACE code can be found in the Appendix, Tabile 3.A.

In the table we present weighted averages of estimated coefficients; weights correspond to the number of the observations. Detailed results of the first stage for each double digit industry are available in Table 4.A (manufacturing) and 5.A. (services).

* Market KIS excludes financial intermediation and high-tech services. 
Table 3: Effects of the ownership structure on the financial efficiency

\begin{tabular}{|c|c|c|c|c|c|c|c|c|c|c|c|c|}
\hline Ownership category & 1996 & 1997 & 1998 & 1999 & 2000 & 2001 & 2002 & 2003 & 2004 & 2005 & 2006 & 2007 \\
\hline Majority foreign & $\begin{array}{l}0.026^{\mathrm{c}} \\
(0.015)\end{array}$ & $\begin{array}{l}0.031^{\mathrm{a}} \\
(0.012)\end{array}$ & $\begin{array}{l}0.056^{\mathrm{a}} \\
(0.011)\end{array}$ & $\begin{array}{l}0.061^{\mathrm{a}} \\
(0.009)\end{array}$ & $\begin{array}{l}0.048^{\mathrm{a}} \\
(0.008)\end{array}$ & $\begin{array}{l}0.044^{\mathrm{a}} \\
(0.007)\end{array}$ & $\begin{array}{l}0.071^{\mathrm{a}} \\
(0.008)\end{array}$ & $\begin{array}{l}0.083^{\mathrm{a}} \\
(0.008)\end{array}$ & $\begin{array}{l}0.079^{\mathrm{a}} \\
(0.010)\end{array}$ & $\begin{array}{l}0.121^{\mathrm{a}} \\
(0.007)\end{array}$ & $\begin{array}{l}0.124^{\mathrm{a}} \\
(0.007)\end{array}$ & $\begin{array}{l}0.114^{\mathrm{a}} \\
(0.008)\end{array}$ \\
\hline Majority domestic & $\begin{array}{l}0.061^{a} \\
(0.010)\end{array}$ & $\begin{array}{l}0.046^{a} \\
(0.009)\end{array}$ & $\begin{array}{l}0.041^{a} \\
(0.007)\end{array}$ & $\begin{array}{l}0.048^{a} \\
(0.007)\end{array}$ & $\begin{array}{l}0.049^{a} \\
(0.006)\end{array}$ & $\begin{array}{c}0.05^{\mathrm{a}} \\
(0.006)\end{array}$ & $\begin{array}{l}0.094^{\mathrm{a}} \\
(0.008)\end{array}$ & $\begin{array}{l}0.115^{\mathrm{a}} \\
(0.007)\end{array}$ & $\begin{array}{l}0.132^{\mathrm{a}} \\
(0.007)\end{array}$ & $\begin{array}{l}0.12^{\mathrm{a}} \\
(0.006)\end{array}$ & $\begin{array}{l}0.12^{\mathrm{a}} \\
(0.006)\end{array}$ & $\begin{array}{c}0.113 \\
(0.007)\end{array}$ \\
\hline Majority unknown & $\begin{array}{l}0.332^{\mathrm{a}} \\
(0.107)\end{array}$ & $\begin{array}{l}0.162^{\mathrm{a}} \\
(0.058)\end{array}$ & $\begin{array}{l}0.269^{\mathrm{a}} \\
(0.066)\end{array}$ & $\begin{array}{l}0.176^{\mathrm{a}} \\
(0.056)\end{array}$ & $\begin{array}{l}0.159^{\mathrm{a}} \\
(0.029)\end{array}$ & $\begin{array}{l}0.105^{\mathrm{a}} \\
(0.050)\end{array}$ & $\begin{array}{l}0.261^{\mathrm{a}} \\
(0.062)\end{array}$ & $\begin{array}{l}0.206^{\mathrm{a}} \\
(0.006)\end{array}$ & $\begin{array}{l}0.199^{\mathrm{a}} \\
(0.005)\end{array}$ & $\begin{array}{l}0.19^{\mathrm{a}} \\
(0.007)\end{array}$ & $\begin{array}{l}0.198^{\mathrm{a}} \\
(0.006)\end{array}$ & $\begin{array}{l}0.191^{\mathrm{a}} \\
(0.007)\end{array}$ \\
\hline $\begin{array}{l}\text { Monitored majority } \\
\text { foreign }\end{array}$ & $\begin{array}{c}0.001 \\
(0.076)\end{array}$ & $\begin{array}{c}0.072 \\
(0.088)\end{array}$ & $\begin{array}{c}0.002 \\
(0.061)\end{array}$ & $\begin{array}{c}0.001 \\
(0.056)\end{array}$ & $\begin{array}{c}0.015 \\
(0.037)\end{array}$ & $\begin{array}{l}0.042^{\mathrm{c}} \\
(0.030)\end{array}$ & $\begin{array}{l}0.126^{\mathrm{a}} \\
(0.031)\end{array}$ & $\begin{array}{l}0.157^{\mathrm{a}} \\
(0.034)\end{array}$ & $\begin{array}{l}0.094^{\mathrm{c}} \\
(0.049)\end{array}$ & $\begin{array}{l}0.198^{\mathrm{a}} \\
(0.035)\end{array}$ & $\begin{array}{l}0.199^{\mathrm{a}} \\
(0.035)\end{array}$ & $\begin{array}{l}0.219^{\mathrm{a}} \\
(0.038)\end{array}$ \\
\hline $\begin{array}{l}\text { Monitored majority } \\
\text { domestic }\end{array}$ & $\begin{array}{l}0.043^{b} \\
(0.018)\end{array}$ & $\begin{array}{l}0.029^{c} \\
(0.015)\end{array}$ & $\begin{array}{l}0.025^{c} \\
(0.013)\end{array}$ & $\begin{array}{l}0.023^{c} \\
(0.012)\end{array}$ & $\begin{array}{l}0.029^{b} \\
(0.011)\end{array}$ & $\begin{array}{l}0.038^{a} \\
(0.011)\end{array}$ & $\begin{array}{l}0.072^{a} \\
(0.014)\end{array}$ & $\begin{array}{l}0.077^{\mathrm{a}} \\
(0.013)\end{array}$ & $\begin{array}{l}0.091^{\mathrm{a}} \\
(0.013)\end{array}$ & $\begin{array}{l}0.069^{\mathrm{a}} \\
(0.012)\end{array}$ & $\begin{array}{c}0.07^{\mathrm{a}} \\
(0.012)\end{array}$ & $\begin{array}{l}0.062^{\mathrm{a}} \\
(0.013)\end{array}$ \\
\hline $\begin{array}{l}\text { Monitored majority } \\
\text { unknown }\end{array}$ & $\mathrm{N} / \mathrm{A}$ & $\mathrm{N} / \mathrm{A}$ & N/A & $\begin{array}{c}0.016 \\
(0.168) \\
\end{array}$ & $\begin{array}{c}0.025 \\
(0.056) \\
\end{array}$ & $\begin{array}{r}0.072 \\
(0.137) \\
\end{array}$ & $\begin{array}{c}0.01 \\
(0.130) \\
\end{array}$ & $\begin{array}{l}0.202^{\mathrm{a}} \\
(0.012) \\
\end{array}$ & $\begin{array}{r}0.196^{\mathrm{a}} \\
(0.010) \\
\end{array}$ & $\begin{array}{r}0.171^{\mathrm{a}} \\
(0.013) \\
\end{array}$ & $\begin{array}{r}0.189^{\mathrm{a}} \\
(0.012) \\
\end{array}$ & $\begin{array}{l}0.182^{a} \\
(0.013) \\
\end{array}$ \\
\hline Minority foreign & $\begin{array}{l}0.101^{\mathrm{c}} \\
(0.052)\end{array}$ & $\begin{array}{l}0.069^{b} \\
(0.030)\end{array}$ & $\begin{array}{c}0.07^{\mathrm{b}} \\
(0.028)\end{array}$ & $\begin{array}{l}0.047^{\mathrm{c}} \\
(0.025)\end{array}$ & $\begin{array}{l}0.039^{\mathrm{c}} \\
(0.023)\end{array}$ & $\begin{array}{l}0.044^{b} \\
(0.018)\end{array}$ & $\begin{array}{l}0.083^{\mathrm{a}} \\
(0.019)\end{array}$ & $\begin{array}{l}0.103^{\mathrm{a}} \\
(0.022)\end{array}$ & $\begin{array}{l}0.145^{\mathrm{a}} \\
(0.021)\end{array}$ & $\begin{array}{l}0.176^{\mathrm{a}} \\
(0.019)\end{array}$ & $\begin{array}{l}0.151^{\mathrm{a}} \\
(0.019)\end{array}$ & $\begin{array}{l}0.155^{\mathrm{a}} \\
(0.020)\end{array}$ \\
\hline Minority domestic & $\begin{array}{l}0.027^{\mathrm{a}} \\
(0.009)\end{array}$ & $\begin{array}{l}0.034^{\mathrm{a}} \\
(0.008)\end{array}$ & $\begin{array}{l}0.039^{\mathrm{a}} \\
(0.008)\end{array}$ & $\begin{array}{l}0.035^{\mathrm{a}} \\
(0.008)\end{array}$ & $\begin{array}{l}0.041^{\mathrm{a}} \\
(0.008)\end{array}$ & $\begin{array}{l}0.034^{\mathrm{a}} \\
(0.009)\end{array}$ & $\begin{array}{l}0.085^{\mathrm{a}} \\
(0.013)\end{array}$ & $\begin{array}{l}0.099^{\mathrm{a}} \\
(0.013)\end{array}$ & $\begin{array}{l}0.105^{\mathrm{a}} \\
(0.013)\end{array}$ & $\begin{array}{c}0.11^{\mathrm{a}} \\
(0.012)\end{array}$ & $\begin{array}{r}0.104^{\mathrm{a}} \\
(0.012)\end{array}$ & $\begin{array}{l}0.098^{\mathrm{a}} \\
(0.013) \\
\end{array}$ \\
\hline $\begin{array}{l}\text { Controlling minority } \\
\text { foreign }\end{array}$ & $\begin{array}{c}0.001 \\
(0.087)\end{array}$ & $\begin{array}{l}0.115^{b} \\
(0.058)\end{array}$ & $\begin{array}{c}0.011 \\
(0.051)\end{array}$ & $\begin{array}{c}0.008 \\
(0.056)\end{array}$ & $\begin{array}{l}0.062^{c} \\
(0.037)\end{array}$ & $\begin{array}{l}0.063^{c} \\
(0.035)\end{array}$ & $\begin{array}{l}0.145^{\mathrm{a}} \\
(0.032)\end{array}$ & $\begin{array}{l}0.162^{\mathrm{a}} \\
(0.034)\end{array}$ & $\begin{array}{l}0.222^{\mathrm{a}} \\
(0.035)\end{array}$ & $\begin{array}{c}0.25^{\mathrm{a}} \\
(0.034)\end{array}$ & $\begin{array}{l}0.257^{\mathrm{a}} \\
(0.034)\end{array}$ & $\begin{array}{l}0.236^{\mathrm{a}} \\
(0.036)\end{array}$ \\
\hline $\begin{array}{l}\text { Controlling minority } \\
\text { domestic }\end{array}$ & $\begin{array}{l}0.026^{b} \\
(0.011)\end{array}$ & $\begin{array}{l}0.014^{\mathrm{c}} \\
(0.009)\end{array}$ & $\begin{array}{c}0.015 \\
(0.009)\end{array}$ & $\begin{array}{l}0.013^{c} \\
(0.008)\end{array}$ & $\begin{array}{l}0.016^{b} \\
(0.008)\end{array}$ & $\begin{array}{l}0.014^{\mathrm{c}} \\
(0.008)\end{array}$ & $\begin{array}{l}0.037^{\mathrm{a}} \\
(0.010)\end{array}$ & $\begin{array}{l}0.046^{a} \\
(0.010)\end{array}$ & $\begin{array}{l}0.049^{\mathrm{a}} \\
(0.009)\end{array}$ & $\begin{array}{l}0.045^{\mathrm{a}} \\
(0.009) \\
\end{array}$ & $\begin{array}{l}0.048^{\mathrm{a}} \\
(0.009) \\
\end{array}$ & $\begin{array}{l}0.047^{\mathrm{a}} \\
(0.009) \\
\end{array}$ \\
\hline Dispersed foreign & $\begin{array}{c}0.023 \\
(0.110)\end{array}$ & $\begin{array}{l}0.101^{\mathrm{c}} \\
(0.063)\end{array}$ & $\begin{array}{c}0.016 \\
(0.062)\end{array}$ & $\begin{array}{c}0.015 \\
(0.056)\end{array}$ & $\begin{array}{l}0.131^{\mathrm{a}} \\
(0.040)\end{array}$ & $\begin{array}{l}0.157^{\mathrm{a}} \\
(0.034)\end{array}$ & $\begin{array}{l}0.273^{a} \\
(0.037)\end{array}$ & $\begin{array}{l}0.271^{\mathrm{a}} \\
(0.041)\end{array}$ & $\begin{array}{l}0.221^{\mathrm{a}} \\
(0.042)\end{array}$ & $\begin{array}{l}0.236^{\mathrm{a}} \\
(0.038)\end{array}$ & $\begin{array}{l}0.263^{\mathrm{a}} \\
(0.039)\end{array}$ & $\begin{array}{l}0.241^{\mathrm{a}} \\
(0.042)\end{array}$ \\
\hline Dispersed domestic & $\begin{array}{l}0.029^{\mathrm{a}} \\
(0.009)\end{array}$ & $\begin{array}{l}0.028^{\mathrm{a}} \\
(0.009)\end{array}$ & $\begin{array}{l}0.033^{\mathrm{a}} \\
(0.009)\end{array}$ & $\begin{array}{l}0.045^{\mathrm{a}} \\
(0.010)\end{array}$ & $\begin{array}{l}0.059^{\mathrm{a}} \\
(0.012)\end{array}$ & $\begin{array}{l}0.071^{\mathrm{a}} \\
(0.014)\end{array}$ & $\begin{array}{l}0.157^{\mathrm{a}} \\
(0.021)\end{array}$ & $\begin{array}{l}0.196^{\mathrm{a}} \\
(0.022)\end{array}$ & $\begin{array}{l}0.188^{\mathrm{a}} \\
(0.022)\end{array}$ & $\begin{array}{l}0.197^{\mathrm{a}} \\
(0.022)\end{array}$ & $\begin{array}{l}0.217^{\mathrm{a}} \\
(0.021)\end{array}$ & $\begin{array}{l}0.196^{\mathrm{a}} \\
(0.022)\end{array}$ \\
\hline Dispersed unknown & $\mathrm{N} / \mathrm{A}$ & $\begin{array}{l}0.375^{\mathrm{a}} \\
(0.108)\end{array}$ & $\begin{array}{l}0.364^{\mathrm{a}} \\
(0.115)\end{array}$ & $\begin{array}{c}0.006 \\
(0.119) \\
\end{array}$ & $\begin{array}{c}0.076 \\
(0.088) \\
\end{array}$ & $\begin{array}{c}0.104 \\
(0.137) \\
\end{array}$ & $\begin{array}{l}0.161^{\mathrm{c}} \\
(0.110)\end{array}$ & $\begin{array}{r}0.197^{\mathrm{a}} \\
(0.016)\end{array}$ & $\begin{array}{r}0.199^{\mathrm{a}} \\
(0.012)\end{array}$ & $\begin{array}{c}0.18^{\mathrm{a}} \\
(0.017)\end{array}$ & $\begin{array}{c}0.18^{\mathrm{a}} \\
(0.016) \\
\end{array}$ & $\begin{array}{l}0.162^{\mathrm{a}} \\
(0.017)\end{array}$ \\
\hline $\begin{array}{c}\text { Unknown ownership } \\
\text { (1996) }\end{array}$ & $\begin{array}{l}0.048^{\mathrm{a}} \\
(0.003)\end{array}$ & $\begin{array}{l}0.048^{a} \\
(0.003)\end{array}$ & $\begin{array}{l}0.055^{a} \\
(0.003)\end{array}$ & $\begin{array}{l}0.059^{\mathrm{a}} \\
(0.003)\end{array}$ & $\begin{array}{l}0.066^{\mathrm{a}} \\
(0.002)\end{array}$ & $\begin{array}{l}0.083^{a} \\
(0.002)\end{array}$ & $\begin{array}{l}0.198^{a} \\
(0.002)\end{array}$ & $\begin{array}{l}0.231^{a} \\
(0.002)\end{array}$ & $\begin{array}{l}0.247^{\mathrm{a}} \\
(0.001) \\
\end{array}$ & $\begin{array}{l}0.260^{\mathrm{a}} \\
(0.001)\end{array}$ & $\begin{array}{l}0.267^{\mathrm{a}} \\
(0.001) \\
\end{array}$ & $\begin{array}{l}0.256^{\mathrm{a}} \\
(0.001) \\
\end{array}$ \\
\hline $\begin{array}{l}\text { R-squared } \\
\mathrm{N}\end{array}$ & $\begin{array}{l}0.010 \\
3,818 \\
\end{array}$ & $\begin{array}{l}0.010 \\
4,335 \\
\end{array}$ & $\begin{array}{l}0.011 \\
5,248 \\
\end{array}$ & $\begin{array}{l}0.009 \\
6,609 \\
\end{array}$ & $\begin{array}{l}0.009 \\
8,301 \\
\end{array}$ & $\begin{array}{c}0.014 \\
11,242 \\
\end{array}$ & $\begin{array}{c}0.034 \\
27,032 \\
\end{array}$ & $\begin{array}{c}0.029 \\
44.649 \\
\end{array}$ & $\begin{array}{c}0.028 \\
60,238 \\
\end{array}$ & $\begin{array}{c}0.026 \\
72,550 \\
\end{array}$ & $\begin{array}{c}0.025 \\
87,268 \\
\end{array}$ & $\begin{array}{c}0.024 \\
79,418 \\
\end{array}$ \\
\hline
\end{tabular}

Note: ${ }^{\mathrm{a}},{ }^{\mathrm{b}},{ }^{\mathrm{c}}$ denote the statistical significance at $1 \%, 5 \%$, and $10 \%$ levels, respectively. 
Table 4: Ownership effects in manufacturing industries: Sectors by EUROSTAT; all years

\begin{tabular}{|c|c|c|c|c|}
\hline \multirow[b]{2}{*}{ Ownership category } & \multicolumn{4}{|c|}{ Technology } \\
\hline & High & $\begin{array}{l}\text { Medium- } \\
\text { high }\end{array}$ & Medium-low & Low \\
\hline \multirow{2}{*}{ Majority foreign } & $0.14^{\mathrm{a}}$ & $0.017^{\mathrm{a}}$ & $0.031^{\mathrm{a}}$ & $0.022^{\mathrm{a}}$ \\
\hline & $(0.007)$ & $(0.008)$ & $(0.009)$ & $(0.005)$ \\
\hline \multirow{2}{*}{ Majority domestic } & $0.138^{\mathrm{a}}$ & $0.045^{\mathrm{a}}$ & $0.04^{\mathrm{a}}$ & $0.019^{\mathrm{a}}$ \\
\hline & $(0.007)$ & $(0.007)$ & $(0.006)$ & $(0.005)$ \\
\hline \multirow{2}{*}{ Majority unknown } & $0.20^{\mathrm{b}}$ & 0.094 & 0.097 & $0.046^{\mathrm{a}}$ \\
\hline & $(0.007)$ & $(0.010)$ & $(0.011)$ & $(0.007)$ \\
\hline \multirow{2}{*}{$\begin{array}{l}\text { Monitored majority } \\
\text { foreign }\end{array}$} & $0.142^{\mathrm{a}}$ & $0.018^{\mathrm{a}}$ & $0.04^{\mathrm{c}}$ & 0.087 \\
\hline & $(0.028)$ & $(0.027)$ & $(0.039)$ & $(0.025)$ \\
\hline \multirow{2}{*}{$\begin{array}{l}\text { Monitored majority } \\
\text { domestic }\end{array}$} & $0.119^{\mathrm{a}}$ & $0.017^{\mathrm{a}}$ & $0.021^{\mathrm{a}}$ & $0.022^{\mathrm{a}}$ \\
\hline & $(0.012)$ & $(0.012)$ & $(0.011)$ & $(0.008)$ \\
\hline \multirow{2}{*}{$\begin{array}{l}\text { Monitored majority } \\
\text { unknown }\end{array}$} & 0.089 & 0.088 & 0.126 & 0.09 \\
\hline & $(0.013)$ & $(0.022)$ & $(0.024)$ & $(0.013)$ \\
\hline \multirow{2}{*}{ Minority foreign } & $0.02^{\mathrm{a}}$ & $0.034^{\mathrm{a}}$ & $0.057^{\mathrm{a}}$ & $0.018^{\mathrm{a}}$ \\
\hline & $(0.019)$ & $(0.020)$ & $(0.020)$ & $(0.015)$ \\
\hline \multirow{2}{*}{ Minority domestic } & $0.023^{\mathrm{a}}$ & $0.027^{\mathrm{a}}$ & $0.039^{\mathrm{a}}$ & $0.019^{\mathrm{a}}$ \\
\hline & $(0.010)$ & $(0.011)$ & $(0.008)$ & $(0.007)$ \\
\hline \multirow{2}{*}{$\begin{array}{l}\text { Controlling minority } \\
\text { foreign }\end{array}$} & $0.013^{\mathrm{a}}$ & 0.048 & $0.053^{\mathrm{c}}$ & 0.089 \\
\hline & $(0.027)$ & $(0.038)$ & $(0.032)$ & $(0.027)$ \\
\hline \multirow{2}{*}{$\begin{array}{l}\text { Controlling minority } \\
\text { domestic }\end{array}$} & $0.012^{\mathrm{a}}$ & $0.018^{\mathrm{a}}$ & $0.022^{\mathrm{a}}$ & $0.013^{\mathrm{a}}$ \\
\hline & $(0.008)$ & $(0.011)$ & $(0.008)$ & $(0.006)$ \\
\hline \multirow{2}{*}{$\begin{array}{l}\text { Controlling minority } \\
\text { domestic }\end{array}$} & $0.009^{\mathrm{b}}$ & $0.003^{\mathrm{a}}$ & $0.001^{\mathrm{a}}$ & $0.003^{b}$ \\
\hline & $(0.049)$ & $(0.033)$ & $(0.037)$ & $(0.038)$ \\
\hline \multirow{2}{*}{ Dispersed foreign } & 0.125 & 0.125 & 0.103 & 0.089 \\
\hline & $(0.036)$ & $(0.045)$ & $(0.041)$ & $(0.027)$ \\
\hline \multirow{2}{*}{ Dispersed domestic } & $0.071^{\mathrm{a}}$ & $0.06^{\mathrm{a}}$ & $0.056^{\mathrm{a}}$ & $0.041^{\mathrm{a}}$ \\
\hline & $(0.014)$ & $(0.016)$ & $(0.010)$ & $(0.010)$ \\
\hline \multirow{2}{*}{ Dispersed unknown } & 0.094 & $0.035^{\mathrm{a}}$ & $0.044^{\mathrm{a}}$ & 0.076 \\
\hline & $(0.019)$ & $(0.021)$ & $(0.020)$ & $(0.017)$ \\
\hline \multirow{2}{*}{$\begin{array}{l}\text { Unknown ownership } \\
\text { (1996) }\end{array}$} & $0.216^{\mathrm{a}}$ & $0.22^{\mathrm{a}}$ & $0.218^{\mathrm{a}}$ & $0.156^{\mathrm{a}}$ \\
\hline & $(0.001)$ & $(0.002)$ & $(0.002)$ & $(0.001)$ \\
\hline R-squared & 0.023 & 0.042 & 0.039 & 0.026 \\
\hline $\mathrm{N}$ & 24,890 & 10,439 & 11,608 & 19,732 \\
\hline
\end{tabular}

Note: ${ }^{a},{ }^{b},{ }^{c}$ denote the statistical significance at $1 \%, 5 \%$, and $10 \%$ levels respectively. 
Table 5: Ownership effects in service sectors: Sectors by EUROSTAT; all years

\begin{tabular}{|c|c|c|c|c|c|}
\hline Ownership category & $\begin{array}{r}\text { Knowledge- } \\
\text { intensive } \\
\text { services } \\
\text { (KIS) }\end{array}$ & $\begin{array}{r}\text { High-tech } \\
\text { KIS }\end{array}$ & $\begin{array}{r}\text { Market KIS } \\
\text { (1) }\end{array}$ & $\begin{array}{r}\text { Less Knowledge- } \\
\text { intensive Services } \\
\text { (LKIS) }\end{array}$ & $\begin{array}{r}\text { Market } \\
\text { services } \\
\text { less KIS }\end{array}$ \\
\hline Majority foreign & $\begin{array}{l}0.216^{\mathrm{a}} \\
(0.007)\end{array}$ & $\begin{array}{l}0.091^{\mathrm{a}} \\
(0.015)\end{array}$ & $\begin{array}{l}0.248^{\mathrm{a}} \\
(0.008)\end{array}$ & $\begin{array}{l}0.084^{\mathrm{a}} \\
(0.005)\end{array}$ & $\begin{array}{l}0.084^{\mathrm{a}} \\
(0.005)\end{array}$ \\
\hline Majority domestic & $\begin{array}{r}0.185^{\mathrm{a}} \\
(0.005)\end{array}$ & $\begin{array}{r}0.062^{a} \\
(0.013)\end{array}$ & $\begin{array}{l}0.209^{a} \\
(0.006)\end{array}$ & $\begin{array}{l}0.108^{a} \\
(0.004)\end{array}$ & $\begin{array}{l}0.111^{\mathrm{a}} \\
(0.004)\end{array}$ \\
\hline Majority unknown & $\begin{array}{l}0.316^{\mathrm{a}} \\
(0.005) \\
\end{array}$ & $\begin{array}{c}0.222 \\
(0.016) \\
\end{array}$ & $\begin{array}{l}0.326^{\mathrm{a}} \\
(0.006) \\
\end{array}$ & $\begin{array}{l}0.185^{\mathrm{a}} \\
(0.004) \\
\end{array}$ & $\begin{array}{l}0.188^{\mathrm{a}} \\
(0.004) \\
\end{array}$ \\
\hline $\begin{array}{l}\text { Monitored majority } \\
\text { foreign }\end{array}$ & $\begin{array}{c}0.308 \\
(0.030)\end{array}$ & $\begin{array}{l}0.049^{\mathrm{a}} \\
(0.052)\end{array}$ & $\begin{array}{c}0.417 \\
(0.038)\end{array}$ & $\begin{array}{l}0.146^{\mathrm{a}} \\
(0.022)\end{array}$ & $\begin{array}{l}0.149^{\mathrm{a}} \\
(0.022)\end{array}$ \\
\hline Monitored majority & $0.132^{\mathrm{a}}$ & $0.106^{\mathrm{a}}$ & $0.141^{\mathrm{a}}$ & $0.057^{\mathrm{a}}$ & $0.06^{\mathrm{a}}$ \\
\hline domestic & $(0.010)$ & $(0.023)$ & $(0.011)$ & $(0.008)$ & $(0.008)$ \\
\hline Monitored majority & $0.267^{a}$ & $0.109^{\mathrm{a}}$ & $0.293^{\mathrm{a}}$ & $0.108^{\mathrm{a}}$ & $\begin{array}{c}0.199 \\
(0.007)\end{array}$ \\
\hline Minority foreign & $\frac{(0.010)}{0.21^{\mathrm{a}}}$ & $\begin{array}{l}(0.0 \\
0.0 \\
0.0\end{array}$ & $\begin{array}{l}(0.0 \\
0.2 \\
(0.0\end{array}$ & $\frac{(0.0}{0.1}$ & $\frac{(0.007)}{0.16^{\mathrm{a}}}$ \\
\hline Minority domestic & $\begin{array}{l}0.196^{\mathrm{a}} \\
(0.009) \\
\end{array}$ & $\begin{array}{c}(0.044) \\
0.097^{\mathrm{a}} \\
(0.027)\end{array}$ & $\begin{array}{c}(0.018) \\
0.196^{\mathrm{a}} \\
(0.010)\end{array}$ & $\begin{array}{r}0.082^{\mathrm{a}} \\
(0.007)\end{array}$ & $\begin{array}{l}0.086^{\mathrm{a}} \\
(0.007)\end{array}$ \\
\hline Controlling minority & 0.365 & $0.044^{\mathrm{c}}$ & 0.389 & $0.204^{\mathrm{a}}$ & 0.207 \\
\hline $\begin{array}{l}\text { Controlling minority } \\
\text { domestic }\end{array}$ & $\begin{array}{l}0.075^{\mathrm{a}} \\
(0.008)\end{array}$ & $\begin{array}{c}0.05^{\mathrm{a}} \\
(0.015)\end{array}$ & $\begin{array}{c}0.086^{\mathrm{a}} \\
(0.009)\end{array}$ & $\begin{array}{l}0.042^{\mathrm{a}} \\
(0.005)\end{array}$ & $\begin{array}{l}0.041^{\mathrm{a}} \\
(0.005)\end{array}$ \\
\hline Minority domestic (33) & $\begin{array}{c}0.126^{\mathrm{a}} \\
(0.038)\end{array}$ & $\begin{array}{l}0.003^{\mathrm{c}} \\
(0.123)\end{array}$ & $\begin{array}{l}0.029^{\mathrm{a}} \\
(0.051)\end{array}$ & $\begin{array}{l}0.154^{\mathrm{a}} \\
(0.036)\end{array}$ & $\begin{array}{c}0.155 \\
(0.036)\end{array}$ \\
\hline Minority foreign (10) & $\begin{array}{c}0.292 \\
(0.294) \\
\end{array}$ & $\begin{array}{c}0.22 \\
(0.280) \\
\end{array}$ & 0.371 & $\begin{array}{c}0.002 \\
(0.115) \\
\end{array}$ & $\begin{array}{c}0.002 \\
(0.115) \\
\end{array}$ \\
\hline Dispersed foreign & $\begin{array}{l}0.484^{\mathrm{a}} \\
(0.032)\end{array}$ & $\begin{array}{l}0.367^{b} \\
(0.076)\end{array}$ & $\begin{array}{l}0.471^{\mathrm{a}} \\
(0.037)\end{array}$ & $\begin{array}{l}0.139^{\mathrm{a}} \\
(0.024)\end{array}$ & $\begin{array}{l}0.144^{b} \\
(0.025)\end{array}$ \\
\hline Dispersed domestic & $\begin{array}{c}0.226^{\mathrm{a}} \\
(0.014)\end{array}$ & $\begin{array}{l}0.101^{\mathrm{b}} \\
(0.049)\end{array}$ & $\begin{array}{r}0.263^{\mathrm{a}} \\
(0.016)\end{array}$ & $\begin{array}{r}0.182^{\mathrm{a}} \\
(0.011)\end{array}$ & $\begin{array}{l}0.183^{\mathrm{b}} \\
(0.012)\end{array}$ \\
\hline Dispersed unknown & $\begin{array}{c}0.26^{\mathrm{a}} \\
(0.014)\end{array}$ & $\begin{array}{l}0.092^{a} \\
(0.034)\end{array}$ & $\begin{array}{r}0.288^{a} \\
(0.016)\end{array}$ & $\begin{array}{l}0.216^{\mathrm{a}} \\
(0.010)\end{array}$ & $\begin{array}{c}0.215 \\
(0.010)\end{array}$ \\
\hline $\begin{array}{l}\text { Unknown ownership } \\
\text { (1996) }\end{array}$ & $\begin{array}{r}0.354^{\mathrm{a}} \\
(0.001) \\
\end{array}$ & $\begin{array}{c}0.207^{\mathrm{a}} \\
(0.003) \\
\end{array}$ & $\begin{array}{l}0.371^{\mathrm{a}} \\
(0.001)\end{array}$ & $\begin{array}{l}0.207^{\mathrm{a}} \\
(0.001)\end{array}$ & $\begin{array}{l}0.208^{\mathrm{a}} \\
(0.001)\end{array}$ \\
\hline R-squared & 0.031 & 0.036 & 0.027 & 0.019 & 0.019 \\
\hline $\mathrm{N}$ & 141,310 & 10,108 & 120,331 & 154,882 & 156,089 \\
\hline
\end{tabular}

Note: ${ }^{a},{ }^{b},{ }^{c}$ denote the statistical significance at $1 \%, 5 \%$, and $10 \%$ levels respectively. 


\section{Appendix}

Table 1.A: Yearly descriptive statistics for manufacturing sectors by EUROSTAT grouping

\begin{tabular}{|c|c|c|c|c|c|}
\hline \multirow[b]{2}{*}{ year } & \multirow[b]{2}{*}{ Variable } & \multicolumn{4}{|c|}{ Technology } \\
\hline & & High & $\begin{array}{r}\text { Medium- } \\
\text { high }\end{array}$ & $\begin{array}{r}\text { Medium- } \\
\text { low }\end{array}$ & Low \\
\hline \multirow{4}{*}{1996} & Turnover & 15.24 & 15.59 & 15.52 & 15.68 \\
\hline & Working capital & 13.64 & 13.96 & 13.85 & 13.67 \\
\hline & Staff costs & 9.83 & 10.38 & 10.07 & 10.1 \\
\hline & Observations & 91 & 385 & 348 & 442 \\
\hline \multirow{4}{*}{1997} & Turnover & 15.01 & 15.44 & 15.27 & 15.35 \\
\hline & Working capital & 13.55 & 13.82 & 13.57 & 13.41 \\
\hline & Staff costs & 9.94 & 10.29 & 10.02 & 10.03 \\
\hline & Observations & 105 & 415 & 396 & 502 \\
\hline \multirow{4}{*}{1998} & Turnover & 15.01 & 15.52 & 15.35 & 15.44 \\
\hline & Working capital & 13.52 & 13.92 & 13.64 & 13.48 \\
\hline & Staff costs & 9.56 & 10.14 & 9.96 & 9.85 \\
\hline & Observations & 129 & 479 & 469 & 567 \\
\hline \multirow{4}{*}{1999} & Turnover & 14.99 & 15.28 & 15.06 & 15.14 \\
\hline & Working capital & 13.36 & 13.64 & 13.34 & 13.25 \\
\hline & Staff costs & 9.59 & 10.01 & 9.66 & 9.71 \\
\hline & Observations & 146 & 581 & 625 & 722 \\
\hline \multirow{4}{*}{2000} & Turnover & 14.89 & 15.22 & 14.87 & 15.06 \\
\hline & Working capital & 13.19 & 13.53 & 13.11 & 13.12 \\
\hline & Staff costs & 9.58 & 10.01 & 9.57 & 9.71 \\
\hline & Observations & 178 & 753 & 801 & 906 \\
\hline \multirow{4}{*}{2001} & Turnover & 14.89 & 15.09 & 14.72 & 14.89 \\
\hline & Working capital & 13.29 & 13.45 & 13 & 13.03 \\
\hline & Staff costs & 9.46 & 9.9 & 9.37 & 9.52 \\
\hline & Observations & 208 & 955 & 1106 & 1211 \\
\hline \multirow{4}{*}{2002} & Turnover & 13.97 & 14.56 & 14.18 & 14.07 \\
\hline & Working capital & 12.43 & 13.03 & 12.59 & 12.41 \\
\hline & Staff costs & 8.29 & 9.12 & 8.54 & 8.54 \\
\hline & Observations & 386 & 1397 & 1721 & 1925 \\
\hline \multirow{4}{*}{2003} & Turnover & 13.57 & 14.34 & 13.99 & 13.71 \\
\hline & Working capital & 12.1 & 12.82 & 12.4 & 12.08 \\
\hline & Staff costs & 7.61 & 8.69 & 8.1 & 8 \\
\hline & Observations & 592 & 1806 & 2405 & 2744 \\
\hline \multirow{4}{*}{2004} & Turnover & 13.44 & 14.29 & 14.02 & 13.6 \\
\hline & Working capital & 12.04 & 12.75 & 12.41 & 12.03 \\
\hline & Staff costs & 7.43 & 8.52 & 8.05 & 7.68 \\
\hline & Observations & 737 & 2159 & 3016 & 3464 \\
\hline \multirow{4}{*}{2005} & Turnover & 13.29 & 14.14 & 13.84 & 13.36 \\
\hline & Working capital & 11.83 & 12.55 & 12.25 & 11.8 \\
\hline & Staff costs & 7.36 & 8.46 & 7.96 & 7.56 \\
\hline & Observations & 799 & 2352 & 3433 & 3909 \\
\hline \multirow{4}{*}{2006} & Turnover & 13.46 & 14.19 & 14.01 & 13.38 \\
\hline & Working capital & 11.98 & 12.61 & 12.36 & 11.81 \\
\hline & Staff costs & 7.24 & 8.35 & 8.01 & 7.45 \\
\hline & Observations & 924 & 2520 & 3769 & 4217 \\
\hline \multirow{4}{*}{2007} & Turnover & 13.76 & 14.43 & 14.3 & 13.56 \\
\hline & Working capital & 12.21 & 12.84 & 12.64 & 12 \\
\hline & Staff costs & 7.45 & 8.54 & 8.15 & 7.54 \\
\hline & Observations & 823 & 2258 & 3367 & 3731 \\
\hline
\end{tabular}


Table 2.A: Yearly descriptive statistics for service sectors by EUROSTAT grouping

\begin{tabular}{|c|c|c|c|c|c|c|}
\hline year & Variable & $\begin{array}{r}\text { Knowledge- } \\
\text { intensive } \\
\text { services (KIS) }\end{array}$ & $\begin{array}{r}\text { High-tech } \\
\text { KIS }\end{array}$ & $\begin{array}{r}\text { Market } \\
\text { KIS* }\end{array}$ & $\begin{array}{r}\text { Less Knowledge- } \\
\text { intensive Services } \\
\text { (LKIS) }\end{array}$ & $\begin{array}{r}\text { Market } \\
\text { services less } \\
\text { KIS }\end{array}$ \\
\hline \multirow{4}{*}{1996} & Turnover & 14.1 & 14.59 & 1414.02 & 14.97 & 15.01 \\
\hline & Working capital & 12.39 & 12.95 & 12.35 & 12.27 & 12.26 \\
\hline & Staff costs & 7.79 & 8.19 & 7.84 & 8.98 & 8.98 \\
\hline & Observations & 660 & 70 & 489 & 1149 & 1155 \\
\hline \multirow{4}{*}{1997} & Turnover & 13.73 & 14.4 & 13.6 & 14.72 & 14.76 \\
\hline & Working capital & 12.19 & 12.85 & 12.11 & 12.08 & 12.07 \\
\hline & Staff costs & 7.66 & 8.09 & 7.71 & 8.85 & 8.87 \\
\hline & Observations & 793 & 98 & 582 & 1308 & 1314 \\
\hline \multirow{4}{*}{1998} & Turnover & 13.74 & 14.41 & 13.59 & 14.72 & 14.76 \\
\hline & Working capital & 12.32 & 12.96 & 12.23 & 12.23 & 12.22 \\
\hline & Staff costs & 7.59 & 7.92 & 7.68 & 8.75 & 8.75 \\
\hline & Observations & 1010 & 134 & 739 & 1636 & 1651 \\
\hline \multirow{4}{*}{1999} & Turnover & 13.61 & 14.25 & 13.43 & 14.52 & 14.55 \\
\hline & Working capital & 12.08 & 12.79 & 11.93 & 12.03 & 12.01 \\
\hline & Staff costs & 7.47 & 8.02 & 7.48 & 8.68 & 8.69 \\
\hline & Observations & 1290 & 185 & 937 & 2080 & 2094 \\
\hline \multirow{4}{*}{2000} & Turnover & 13.46 & 14.06 & 13.28 & 14.44 & 14.47 \\
\hline & Working capital & 11.93 & 12.58 & 11.74 & 11.92 & 11.9 \\
\hline & Staff costs & 7.45 & 8.17 & 7.39 & 8.63 & 8.64 \\
\hline & Observations & 1535 & 223 & 1121 & 2702 & 2691 \\
\hline \multirow{4}{*}{2001} & Turnover & 13.23 & 13.91 & 12.99 & 14.27 & 14.31 \\
\hline & Working capital & 11.78 & 12.43 & 11.53 & 11.8 & 11.8 \\
\hline & Staff costs & 7.53 & 8.02 & 7.45 & 8.44 & 8.46 \\
\hline & Observations & 1930 & 280 & 1423 & 4001 & 3993 \\
\hline \multirow{4}{*}{2002} & Turnover & 11.81 & 12.91 & 11.56 & 12.99 & 13 \\
\hline & Working capital & 10.37 & 11.42 & 10.09 & 10.92 & 10.91 \\
\hline & Staff costs & 6.46 & 6.97 & 6.39 & 7.34 & 7.35 \\
\hline & Observations & 7265 & 716 & 5878 & 10865 & 10926 \\
\hline \multirow{4}{*}{2003} & Turnover & 11.7 & 12.67 & 11.5 & 12.73 & 12.74 \\
\hline & Working capital & 10.26 & 11.19 & 10.02 & 10.75 & 10.74 \\
\hline & Staff costs & 6.17 & 6.48 & 6.15 & 6.97 & 6.98 \\
\hline & Observations & 13492 & 1227 & 11014 & 18302 & 18442 \\
\hline \multirow{4}{*}{2004} & Turnover & 11.72 & 12.65 & 11.53 & 12.74 & 12.75 \\
\hline & Working capital & 10.28 & 11.24 & 10.05 & 10.77 & 10.76 \\
\hline & Staff costs & 6.15 & 6.51 & 6.13 & 6.87 & 6.88 \\
\hline & Observations & 19416 & 1564 & 16171 & 24493 & 24680 \\
\hline \multirow{4}{*}{2005} & Turnover & 11.3 & 12.45 & 11.11 & 12.58 & 12.59 \\
\hline & Working capital & 9.9 & 11.11 & 9.64 & 10.68 & 10.67 \\
\hline & Staff costs & 6.02 & 6.37 & 5.98 & 6.83 & 6.84 \\
\hline & Observations & 26100 & 1757 & 22391 & 28020 & 28246 \\
\hline \multirow{4}{*}{2006} & Turnover & 11.21 & 12.57 & 10.99 & 12.68 & 12.69 \\
\hline & Working capital & 9.78 & 11.26 & 9.51 & 10.82 & 10.82 \\
\hline & Staff costs & 5.93 & 6.38 & 5.87 & 6.83 & 6.83 \\
\hline & Observations & 34922 & 2025 & 30565 & 31962 & 32272 \\
\hline \multirow{4}{*}{2007} & Turnover & 11.35 & 12.79 & 11.14 & 12.91 & 12.92 \\
\hline & Working capital & 9.88 & 11.48 & 9.61 & 11.05 & 11.05 \\
\hline & Staff costs & 6.07 & 6.57 & 6.01 & 6.94 & 6.94 \\
\hline & Observations & 32897 & 1829 & 29021 & 28364 & 28625 \\
\hline
\end{tabular}

Note: * Market KIS excludes financial intermediation and high-tech services. Used groups are not mutually exclusive. 
Table 3.A: Description and distribution of industries

\begin{tabular}{|c|c|c|c|}
\hline \multicolumn{4}{|c|}{ Manufacturing: High-technology } \\
\hline 30 & Manufacture of office machinery and computers & 479 & $0.12 \%$ \\
\hline 32 & $\begin{array}{l}\text { Manufacture of radio, television and communication equipment and } \\
\text { apparatus }\end{array}$ & 1792 & $0.44 \%$ \\
\hline 33 & $\begin{array}{l}\text { Manufacture of medical, precision and optical instruments, watches and } \\
\text { clocks }\end{array}$ & 1836 & $0.45 \%$ \\
\hline Total & & 4107 & $1.01 \%$ \\
\hline \multicolumn{4}{|c|}{ Manufacturing: Medium-high-technology } \\
\hline 24 & Manufacture of chemicals and chemical products & 2310 & $0.56 \%$ \\
\hline 29 & Manufacture of machinery and equipment n.e.c. & 7461 & $1.82 \%$ \\
\hline 31 & Manufacture of electrical machinery and apparatus n.e.c. & 4597 & $1.12 \%$ \\
\hline 34 & Manufacture of motor vehicles, trailers and semi-trailers & 1257 & $0.31 \%$ \\
\hline 35 & Manufacture of other transport equipment & 672 & $0.16 \%$ \\
\hline Total & & 16297 & $3.97 \%$ \\
\hline \multicolumn{4}{|c|}{ Manufacturing: Medium-low-technology } \\
\hline 25 & Manufacture of rubber and plastic products & 3983 & $0.97 \%$ \\
\hline 26 & Manufacture of other non-metallic mineral products & 3250 & $0.79 \%$ \\
\hline 27 & Manufacture of basic metals & 1394 & $0.34 \%$ \\
\hline 28 & Manufacture of fabricated metal products, except machinery and eqp. & 12686 & $3.09 \%$ \\
\hline Total & & 21313 & $5.19 \%$ \\
\hline \multicolumn{4}{|c|}{ Manufacturing: Low-technology } \\
\hline 15 & Manufacture of food products and beverages & 6754 & $1.64 \%$ \\
\hline 17 & Manufacture of textiles & 2115 & $0.51 \%$ \\
\hline 18 & Manufacture of wearing apparel; dressing and dyeing of fur & 1528 & $0.37 \%$ \\
\hline 19 & $\begin{array}{l}\text { Tanning and dressing of leather; manufacture of luggage, handbags, saddlery, } \\
\text { harness and footwear }\end{array}$ & 539 & $0.13 \%$ \\
\hline 20 & $\begin{array}{l}\text { Manufacture of wood and of products of wood and cork, except furniture; } \\
\text { manufacture of articles of straw and plaiting materials }\end{array}$ & 4216 & $1.03 \%$ \\
\hline 21 & Manufacture of pulp, paper and paper products & 967 & $0.24 \%$ \\
\hline 22 & Publishing, printing and reproduction of recorded media & 4795 & $1.17 \%$ \\
\hline 36 & Manufacture of furniture; manufacturing n.e.c. & 2907 & $0.71 \%$ \\
\hline 37 & Recycling & 519 & $0.13 \%$ \\
\hline Total & & 24340 & $5.93 \%$ \\
\hline \multicolumn{4}{|c|}{ Unassigned sectors } \\
\hline 1 & Agriculture, hunting and related service activities & 12144 & $2.96 \%$ \\
\hline 2 & Forestry, logging and related service activities & 1363 & $0.33 \%$ \\
\hline 14 & Other mining and quarrying & 612 & $0.15 \%$ \\
\hline 40 & Electricity, gas, steam and hot water supply & 1588 & $0.39 \%$ \\
\hline 41 & Collection, purification and distribution of water & 765 & $0.19 \%$ \\
\hline 45 & Construction & 27456 & $6.69 \%$ \\
\hline Total & & 43928 & $10.71 \%$ \\
\hline
\end{tabular}


Table 3.A. Description and distribution of industries - continued

NACE Industry

64 Post and telecommunications

65 Financial intermediation, except insurance and pension funding

70 Real estate activities

71 Renting of machinery and equipment without operator and of personal and household goods

72 Computer and related activities

73 Research and development

74 Other business activities

80 Education

85 Health and social work

92 Recreational, cultural and sporting activities
Obs. Share

\begin{tabular}{rr}
1327 & $0.32 \%$ \\
956 & $0.23 \%$ \\
67332 & $16.39 \%$ \\
& \\
2435 & $0.59 \%$ \\
8033 & $1.96 \%$ \\
748 & $0.18 \%$ \\
50564 & $12.31 \%$ \\
2627 & $0.64 \%$ \\
2960 & $0.72 \%$ \\
4328 & $1.05 \%$ \\
141310 & $34.39 \%$ \\
\hline
\end{tabular}

High-tech KIS

64 Post and telecommunications

72 Computer and related activities

$1327 \quad 0.32 \%$

$8033 \quad 1.96 \%$

$748 \quad 0.18 \%$

Market KIS (excludes financial intermediation and high-tech services)

70 Real estate activities

$67332 \quad 16.39 \%$

71 Renting of machinery and equipment without operator and of personal and household goods

$2435 \quad 0.59 \%$

74 Other business activities

$50564 \quad 12.31 \%$

Less Knowledge-intensive services (LKIS)

50 Sale, maintenance and repair of motor vehicles and motorcycles; retail sale of automotive fuel

$7860 \quad 1.91 \%$

51 Wholesale trade and commission trade, except of motor vehicles and motorcycles

$74821 \quad 18.22 \%$

52 Retail trade, except of motor vehicles and motorcycles; repair of personal and household goods

$52702 \quad 12.83 \%$

$9673 \quad 2.36 \%$

$6502 \quad 1.58 \%$

$4531 \quad 1.10 \%$

$2279 \quad 0.55 \%$

$1045 \quad 0.25 \%$

$159413 \quad 38.80 \%$

\section{Market services less KIS}

Sale, maintenance and repair of motor vehicles and motorcycles; retail sale of

50 automotive fuel

$7860 \quad 1.91 \%$

Wholesale trade and commission trade, except of motor vehicles and

51 motorcycles

$74821 \quad 18.22 \%$

Retail trade, except of motor vehicles and motorcycles; repair of personal and

52 household goods

$52702 \quad 12.83 \%$

$9673 \quad 2.36 \%$

$6502 \quad 1.58 \%$

$4531 \quad 1.10 \%$

60 Land transport; transport via pipelines
63 Supporting and auxiliary transport activities; activities of travel agencies 
Table 4.A: First step - efficiency frontiers by two-digit NACE industry (Manufacturing)

\begin{tabular}{|c|c|c|c|c|c|c|}
\hline \multirow{2}{*}{$\begin{array}{l}\text { 2-Digit } \\
\text { NACE Industry }\end{array}$} & \multicolumn{2}{|c|}{ Constant } & \multicolumn{2}{|c|}{ Working capital } & \multicolumn{2}{|c|}{ Staff costs } \\
\hline & Coef. & Std. Err. & Coef. & Std. Err. & Coef. & Std. Err. \\
\hline \multicolumn{7}{|c|}{ High-technology manufacturing } \\
\hline Office machinery and computers & $13.052^{\mathrm{a}}$ & 0.354 & $0.242^{\mathrm{a}}$ & 0.024 & $0.657^{\mathrm{a}}$ & 0.034 \\
\hline Radio, television and communication equipment and apparatus & $12.987^{\mathrm{a}}$ & 0.225 & $0.148^{\mathrm{a}}$ & 0.016 & $0.699^{\mathrm{a}}$ & 0.021 \\
\hline Medical, precision and optical instruments, watches and clocks & $13.058^{\mathrm{a}}$ & 0.243 & $0.157^{\mathrm{a}}$ & 0.018 & $0.674^{\mathrm{a}}$ & 0.023 \\
\hline \multicolumn{7}{|c|}{ Medium-high-technology manufacturing } \\
\hline Chemicals and chemical products & $12.355^{\mathrm{a}}$ & 0.220 & $0.143^{\mathrm{a}}$ & 0.017 & $0.775^{\mathrm{a}}$ & 0.021 \\
\hline Machinery and equipment n.e.c. & $12.879^{\mathrm{a}}$ & 0.147 & $0.112^{\mathrm{a}}$ & 0.011 & $0.737^{\mathrm{a}}$ & 0.013 \\
\hline Electrical machinery and apparatus n.e.c. & $13.188^{\mathrm{a}}$ & 0.157 & $0.134^{\mathrm{a}}$ & 0.012 & $0.696^{\mathrm{a}}$ & 0.014 \\
\hline Motor vehicles, trailers and semi-trailers & $11.031^{\mathrm{a}}$ & 0.268 & $0.126^{\mathrm{a}}$ & 0.018 & $0.878^{\mathrm{a}}$ & 0.023 \\
\hline Other transport equipment & $8.428^{\mathrm{a}}$ & 0.359 & $0.042^{\mathrm{c}}$ & 0.030 & $1.100^{\mathrm{a}}$ & 0.032 \\
\hline \multicolumn{7}{|c|}{ Medium-low-technology manufacturing } \\
\hline Rubber and plastic products & $11.877^{\mathrm{a}}$ & 0.177 & $0.100^{\mathrm{a}}$ & 0.013 & $0.835^{\mathrm{a}}$ & 0.016 \\
\hline Other non-metallic mineral products & $12.095^{\mathrm{a}}$ & 0.191 & $0.137^{\mathrm{a}}$ & 0.015 & $0.784^{\mathrm{a}}$ & 0.018 \\
\hline Basic metals & $12.538^{\mathrm{a}}$ & 0.296 & $0.112^{\mathrm{a}}$ & 0.020 & $0.778^{\mathrm{a}}$ & 0.025 \\
\hline Fabricated metal products, except machinery and equipment & $12.897^{\mathrm{a}}$ & 0.128 & $0.091^{\mathrm{a}}$ & 0.010 & $0.748^{\mathrm{a}}$ & 0.012 \\
\hline \multicolumn{7}{|l|}{ Low-technology manufacturing } \\
\hline Food products and beverages & $12.890^{\mathrm{a}}$ & 0.148 & $0.123^{\mathrm{a}}$ & 0.011 & $0.754^{\mathrm{a}}$ & 0.013 \\
\hline Textiles & $12.921^{\mathrm{a}}$ & 0.218 & $0.240^{\mathrm{a}}$ & 0.016 & $0.636^{\mathrm{a}}$ & 0.020 \\
\hline Wearing apparel; dressing and dyeing of fur & $13.591^{\mathrm{a}}$ & 0.264 & $0.148^{\mathrm{a}}$ & 0.018 & $0.627^{\mathrm{a}}$ & 0.024 \\
\hline $\begin{array}{l}\text { Tanning and dressing of leather; manufacture of luggage, handbags, saddlery, } \\
\text { harness and footwear }\end{array}$ & $14.129^{\mathrm{a}}$ & 0.440 & $0.136^{\mathrm{a}}$ & 0.030 & $0.611^{\mathrm{a}}$ & 0.040 \\
\hline $\begin{array}{l}\text { Wood and products of wood and cork, except furniture; articles of straw and plaiting } \\
\text { materials }\end{array}$ & $13.389^{\mathrm{a}}$ & 0.170 & $0.134^{\mathrm{a}}$ & 0.013 & $0.678^{\mathrm{a}}$ & 0.016 \\
\hline Pulp, paper and paper products & $14.757^{\mathrm{a}}$ & 0.266 & $0.195^{\mathrm{a}}$ & 0.023 & $0.551^{\mathrm{a}}$ & 0.022 \\
\hline Publishing, printing and reproduction of recorded media & $13.782^{\mathrm{a}}$ & 0.167 & $0.109^{\mathrm{a}}$ & 0.012 & $0.661^{\mathrm{a}}$ & 0.016 \\
\hline Furniture & $12.651^{\mathrm{a}}$ & 0.204 & $0.107^{\mathrm{a}}$ & 0.015 & $0.746^{\mathrm{a}}$ & 0.019 \\
\hline Recycling & $12.127^{\mathrm{a}}$ & 0.437 & $0.117^{\mathrm{a}}$ & 0.027 & $0.824^{\mathrm{a}}$ & 0.040 \\
\hline
\end{tabular}

Note: Industry Classification according to OECD-Eurostat (Laafia 2002). It is also available at http://epp.eurostat.ec.europa.eu/cache/ITY_SDDS/Annexes/htec_esms_an2.pdf .

${ }^{\mathrm{a}},{ }^{\mathrm{b}},{ }^{\mathrm{c}}$ denotes the significance on $1 \%, 5 \%$, and $10 \%$ level respectively. 
Table 5.A: First step - efficiency frontiers by two-digit NACE industry (Service)

\begin{tabular}{|c|c|c|c|c|c|c|}
\hline \multirow{2}{*}{$\begin{array}{l}\text { 2-Digit } \\
\text { NACE Industry }\end{array}$} & \multicolumn{2}{|c|}{ Constant } & \multicolumn{2}{|c|}{ Working capital } & \multicolumn{2}{|c|}{ Staff costs } \\
\hline & Coef. & Std. Err. & Coef. & Std. Err. & Coef. & Std. Err. \\
\hline \multicolumn{7}{|c|}{ Knowledge-intensive services (KIS) } \\
\hline Post and telecommunications & $13.628^{\mathrm{a}}$ & 0.269 & $0.127^{\mathrm{a}}$ & 0.018 & $0.704^{\mathrm{a}}$ & 0.026 \\
\hline Financial intermediation, except insurance and pension funding & $12.331^{\mathrm{a}}$ & 0.405 & 0.008 & 0.019 & $0.902^{\mathrm{a}}$ & 0.038 \\
\hline Real estate activities & $13.221^{\mathrm{a}}$ & 0.106 & $0.137^{\mathrm{a}}$ & 0.009 & $0.673^{\mathrm{a}}$ & 0.010 \\
\hline $\begin{array}{l}\text { Renting of machinery and equipment without operator and of personal and household } \\
\text { goods }\end{array}$ & $13.636^{\mathrm{a}}$ & 0.195 & $0.135^{\mathrm{a}}$ & 0.014 & $0.677^{\mathrm{a}}$ & 0.018 \\
\hline Computer and related activities & $14.233^{\mathrm{a}}$ & 0.141 & $0.110^{\mathrm{a}}$ & 0.010 & $0.610^{\mathrm{a}}$ & 0.013 \\
\hline Research and development & $13.072^{\mathrm{a}}$ & 0.360 & $0.095^{\mathrm{a}}$ & 0.023 & $0.698^{\mathrm{a}}$ & 0.032 \\
\hline Other business activities & $13.599^{\mathrm{a}}$ & 0.105 & $0.112^{\mathrm{a}}$ & 0.008 & $0.666^{\mathrm{a}}$ & 0.009 \\
\hline Education & $13.976^{\mathrm{a}}$ & 0.230 & $0.122^{\mathrm{a}}$ & 0.016 & $0.558^{\mathrm{a}}$ & 0.021 \\
\hline Health and social work & $12.853^{\mathrm{a}}$ & 0.225 & $0.064^{\mathrm{a}}$ & 0.014 & $0.729^{\mathrm{a}}$ & 0.020 \\
\hline Recreational, cultural and sporting activities & $15.714^{\mathrm{a}}$ & 0.179 & $0.138^{\mathrm{a}}$ & 0.012 & $0.499^{\mathrm{a}}$ & 0.017 \\
\hline \multicolumn{7}{|l|}{ High-tech KIS } \\
\hline Post and telecommunications & $13.628^{\mathrm{a}}$ & 0.269 & $0.127^{\mathrm{a}}$ & 0.018 & $0.704^{\mathrm{a}}$ & 0.026 \\
\hline Computer and related activities & $14.233^{\mathrm{a}}$ & 0.141 & $0.110^{\mathrm{a}}$ & 0.010 & $0.610^{\mathrm{a}}$ & 0.013 \\
\hline Research and development & $13.072^{\mathrm{a}}$ & 0.360 & $0.095^{\mathrm{a}}$ & 0.023 & $0.698^{\mathrm{a}}$ & 0.032 \\
\hline \multicolumn{7}{|c|}{ Market KIS (excludes financial intermediation and high-tech services) } \\
\hline Real estate activities & $13.221^{\mathrm{a}}$ & 0.106 & $0.137^{\mathrm{a}}$ & 0.009 & $0.673^{\mathrm{a}}$ & 0.010 \\
\hline $\begin{array}{l}\text { Renting of machinery and equipment without operator and of personal and household } \\
\text { goods }\end{array}$ & $13.636^{\mathrm{a}}$ & 0.195 & $0.135^{\mathrm{a}}$ & 0.014 & $0.677^{\mathrm{a}}$ & 0.018 \\
\hline Other business activities & $13.599^{\mathrm{a}}$ & 0.105 & $0.112^{\mathrm{a}}$ & 0.008 & $0.666^{\mathrm{a}}$ & 0.009 \\
\hline \multicolumn{7}{|c|}{ Less knowledge-intensive services } \\
\hline $\begin{array}{l}\text { Sale, maintenance and repair of motor vehicles and motorcycles; retail sale of } \\
\text { automotive fuel }\end{array}$ & $13.460^{\mathrm{a}}$ & 0.141 & $0.157^{\mathrm{a}}$ & 0.011 & $0.705^{\mathrm{a}}$ & 0.013 \\
\hline Wholesale trade and commission trade, except of motor vehicles and motorcycles & $14.172^{\mathrm{a}}$ & 0.100 & $0.170^{\mathrm{a}}$ & 0.008 & $0.621^{\mathrm{a}}$ & 0.009 \\
\hline Retail trade, except of motor vehicles and motorcycles; repair of personal and hh goods & $14.009^{\mathrm{a}}$ & 0.103 & $0.165^{\mathrm{a}}$ & 0.008 & $0.621^{\mathrm{a}}$ & 0.009 \\
\hline Hotels and restaurants & $13.346^{\mathrm{a}}$ & 0.132 & $0.127^{\mathrm{a}}$ & 0.011 & $0.664^{\mathrm{a}}$ & 0.012 \\
\hline Land transport; transport via pipelines & $12.942^{\mathrm{a}}$ & 0.154 & $0.074^{\mathrm{a}}$ & 0.011 & $0.776^{\mathrm{a}}$ & 0.014 \\
\hline Supporting and auxiliary transport activities; activities of travel agencies & $13.910^{\mathrm{a}}$ & 0.188 & $0.070^{\mathrm{a}}$ & 0.011 & $0.720^{\mathrm{a}}$ & 0.017 \\
\hline
\end{tabular}

Note: Industry Classification according to OECD-Eurostat (Laafia 2002). It is also available at

http://epp.eurostat.ec.europa.eu/cache/ITY_SDDS/Annexes/htec_esms_an2.pdf. a , b , c denotes the significance on 1\%, 5\%, and 10\% level respectively. 


\section{DAVIDSON INSTITUTE WORKING PAPER SERIES - Most Recent Papers}

The entire Working Paper Series may be downloaded free of charge at: www.wdi.umich.edu

CURRENT AS OF 5/19/11

\begin{tabular}{|c|c|c|}
\hline Publication & Authors & Date \\
\hline No. 1016: Financial Efficiency and the Ownership of Czech Firms & $\begin{array}{l}\text { Evzen Kocenda, Jan Hanousek } \\
\text { and Michal Masika }\end{array}$ & May 2011 \\
\hline $\begin{array}{l}\text { No. 1015: Default Predictors in Retail Credit Scoring: Evidence from } \\
\text { Czech Banking Data }\end{array}$ & Evzen Kocenda \& Martin Vojtek & April 2011 \\
\hline $\begin{array}{l}\text { No. 1014: Exchange Rate Pass-Through in Transition Economies: The } \\
\text { Case of Republic of Macedonia }\end{array}$ & Besnik Fetai & April 2011 \\
\hline $\begin{array}{l}\text { No. 1013: Establishing Data Collection Procedures Equivalence in } \\
\text { International Business Research }\end{array}$ & $\begin{array}{l}\text { Agnieszka Chidlow \& } \\
\text { Pervez N. Ghauri }\end{array}$ & $\begin{array}{l}\text { March } \\
2011\end{array}$ \\
\hline $\begin{array}{l}\text { No. 1012: The Link between Innovation and Productivity in Estonia's } \\
\text { Service Sectors }\end{array}$ & Priit Vahter \& Jaan Masso & $\begin{array}{l}\text { March } \\
2011\end{array}$ \\
\hline $\begin{array}{l}\text { No. 1011: Learning by exporting: evidence based on data of knowledge } \\
\text { flows from innovation surveys in Estonia }\end{array}$ & Priit Vahter & Feb 2011 \\
\hline $\begin{array}{l}\text { No. 1010: Firm Investment \& Credit Constraints in India, } 1997 \text { - 2006: } \\
\text { A stochastic frontier approach }\end{array}$ & $\begin{array}{l}\text { Sumon Bhaumik, Pranab Kumar } \\
\text { Das and Subal C. Kumbhakar }\end{array}$ & Jan 2011 \\
\hline No. 1009: Industrial Enlargement And Competitiveness Index & Art Kovacic & Jan 2011 \\
\hline $\begin{array}{l}\text { NO. 1008: SUPPORTING AFRICA'S POST-CRISIS GROWTH: THE ROLE OF } \\
\text { MACROECONOMIC POLICIES }\end{array}$ & $\begin{array}{l}\text { Zuzana Brixiova, Leonce } \\
\text { Ndikumana \& Kaouther } \\
\text { Abderrahim }\end{array}$ & Jan 2011 \\
\hline $\begin{array}{l}\text { No. 1007: The Funding \& Efficiency of Higher Education in Croatia \& } \\
\text { Slovenia: A Non-Parametric Comparison w/ the EU \& OECD Countries. }\end{array}$ & $\begin{array}{l}\text { Aleksander Aristovnik and } \\
\text { Alka Obadic }\end{array}$ & Jan 2011 \\
\hline $\begin{array}{l}\text { No. 1006: Public Investment and Fiscal Performance in New EU } \\
\text { Member States }\end{array}$ & Jan Hanousek and Evžen Kočenda & Dec 2010 \\
\hline No. 1005: Is Monetary Policy in New Member States Asymmetric? & Bořek Vašíček & Dec. 2010 \\
\hline $\begin{array}{l}\text { No. 1004: Inflation Targeting in Brazil, Chile \& South Africa: An } \\
\text { Empirical Investigation of Their Monetary Policy Framework }\end{array}$ & Mona Kamal & Nov. 2010 \\
\hline $\begin{array}{l}\text { No. 1003: Assessing Mondragon: Stability and Managed Change in the } \\
\text { Face of Globalization }\end{array}$ & $\begin{array}{l}\text { Saioa Arando, Fred Freundlich, } \\
\text { Monica Gago, Derek C. Jones } \\
\text { and Takao Kato }\end{array}$ & Nov. 2010 \\
\hline $\begin{array}{l}\text { No. 1002: Money Market Integration and Sovereign CDS Spreads } \\
\text { Dynamics in the New EU States }\end{array}$ & $\begin{array}{l}\text { Peter Chobanov, Amine Lahiani } \\
\text { and Nikolay Nenovsky }\end{array}$ & Oct 2010 \\
\hline No. 1001: Modeling transition in Central Asia: the Case of Kazakhstan & $\begin{array}{l}\text { Gilles DUFRENOT, Adelya } \\
\text { OSPANOVA, Alain SAND- } \\
\text { Zantman }\end{array}$ & Oct 2010 \\
\hline $\begin{array}{l}\text { No.1000: Unlocking Productive Entrepreneurship in Ethiopia: } \\
\text { Which Incentives Matter? }\end{array}$ & $\begin{array}{l}\text { Zuzana Brixiova \& } \\
\text { Emerta Asaminew }\end{array}$ & Oct 2010 \\
\hline No.999: Price convergence and market integration in Russia & Konstantin Gluschenko & Sept 2010 \\
\hline $\begin{array}{l}\text { No. 998: Bank Efficiency in Transitional Countries: Sensitivity to } \\
\text { Stochastic Frontier Design }\end{array}$ & Zuzana Irsova & Sept 2010 \\
\hline $\begin{array}{l}\text { No. 997: EU Enlargement and Monetary Regimes from the Insurance } \\
\text { Model Perspectives }\end{array}$ & Nikolay Nenovsky & June 2010 \\
\hline $\begin{array}{l}\text { No. 996: Which Foreigners are Worth Wooing? } \\
\text { A Meta-Analysis of Vertical Spillovers from FDI }\end{array}$ & $\begin{array}{l}\text { Tomas Havranek and } \\
\text { Zuzana Irsova }\end{array}$ & June 2010 \\
\hline $\begin{array}{l}\text { No. 995: Environmental Regulation and Competitiveness: } \\
\text { Evidence from Romania }\end{array}$ & $\begin{array}{c}\text { Guglielmo M. Caporale, } \\
\text { Christophe Rault, Robert Sova \& } \\
\text { Anamaria Sova }\end{array}$ & June 2010 \\
\hline
\end{tabular}

